\title{
Janusz Siatkowski
}

\section{Słowiańskie nazwy 'pleców' i 'ramienia' w świetle materiałów gwarowych i źródeł historycznych}

'Plecy' i 'ramię' mają tylko jedną grupę nazw współrdzennych, występujących w obu tych znaczeniach. Pochodzą one od rdzenia * pletj-, oznaczonego na obu mapach szarą plamą. Na mapie 'pleców' szara plama bez znaku oznacza najbardziej rozpowszechnioną formę *pletji, na mapie 'ramienia' zaś również najczęstszą formę ${ }^{*}$ pletj-E. W obu znaczeniach wystąpiła głównie jedna forma ${ }^{*}$ pletji. Pozostałe formacje, oznaczone różnie wypełnionym wewnątrz kółkiem umieszczonym na szarym tle, mają zazwyczaj jedno lub drugie znaczenie. W nazwach 'pleców' widać pewną komplikację semantyczną. Zanotowano tu również nazwy odnoszące się częściej do ich części: górnej ('barki') lub dolnej (tzw. 'krzyże'). Szczegółowe zestawienia z materiałami porównawczymi pokazują, że nie są to pomyłki, a nawet nie tylko doraźne przeniesienia, ponieważ znajdują potwierdzenie także w innych źródłach. Z kolei nazwy 'ramienia' odnoszą się zarówno do 'barku - górnej części pleców poniżej karku, od kręgosłupa do początku ręki', jak i do 'części ręki od barku do łokcia (lub nawet aż do dłoni)'. W wypadku form liczby mnogiej prowadzi to do mieszania nazw dla 'pleców' i 'ramion'.

Mapy dla 'pleców' i 'ramienia' zostały przedstawione w 9. tomie OLA - niezależnie - za pomocą znaków punktowych. Tu w opracowaniu Profesor Doroty Rembiszewskiej zastosowano jednakową na obu mapach syntetyczną technikę płaszczyzn ze szrafowaniem oraz znaki punktowe. 


\section{plecy}

W znaczeniu 'plecy' od wspomnianego rdzenia * pletj- zanotowano trzy formacje ${ }^{\star}$ pletji, ${ }^{\star}$ plexy $\mathrm{i}{ }^{\star}$ pletja.

Pierwsza ${ }^{*}$ pletji, stanowiąca dzisiaj formę liczby mnogiej, wywodzi się najpewniej z dawnej liczby podwójnej od rzeczownika rodzaju nijakiego ${ }^{\star}$ pletje. Tak traktuje polską formę plecy SStp VI 149-150 i sch. formę pleći RHSJ X 34.

Tworzy ona zwarty areał, oznaczony na mapie szarą płaszczyzną, obejmujący całą Polskę (plecy, pl'ecy, na Kaszubach p'leca, p'le $e^{i} c e$, a w p. 266 we wschodniosłowiańskiej postaci fonetycznej plečy; tu trudniej przyjąć hiperyzm wobec mazurzenia) oraz południowo-zachodnią Ukrainę ( $p^{\prime} \nmid e c^{\prime} i, p^{\prime} ł e c ̌ y, p^{\prime} l e c c^{\prime} i$, p'leči itp.). Na Ukrainie jej zwarty wschodni zasięg wyznacza linia biegnąca od pogranicza polsko-białorusko-ukraińskiego aż po punkty ukraińskie w Mołdawii. Od wschodu z kompleksem tym sąsiaduje wschodniosłowiańska *spina. Granica między obu tymi nazwami jest dosyć ostra - jedynie w dwóch punktach granicznych zapisano obie nazwy: w p. 361 koło Brześcia oraz w p. 524 na terenie Mołdawii. Na zachód od tej linii nazwę ${ }^{*}$ spina odnotowano tylko w trzech punktach ukraińskich: koło Drohobycza (s'psna - 428), na Zakarpaciu (s'pyna obok xrbı'bet - 484) i na północ od Kamieńca Podolskiego (s'pyna obok $\left.p^{\prime} ł e c c^{\prime} i-488\right)$. Natomiast na wschód od linii granicznej * pletji zanotowano w kilku, nieraz nawet bardzo odległych, wyspach - na Białorusi ( $p l ' e c ̌ b l): ~ n a$ pograniczu litewsko-łotewskim (327, 329, 332, 340), wokół Mińska (357, 367, 368), koło Nowogródka (347) i nad środkową Prypecią (389) oraz na Ukrainie: koło Łucka (p'łečy - 408), na pograniczu białoruskim (p'l'ečı 410, koło Owruczy

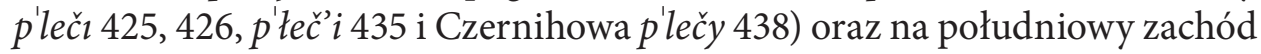
od Kijowa (p'l'eči i 475).

W języku polskim plecy notowane są od XV wieku, poza tym występowały formy plece n., plec m., plec f., pleca f. sg., pleca plt. (SStp VI 149-150, SP XVI t. XXIV 328-329, Linde IV 149-150). Oprócz znaczenia 'plecy' pojawiają się też 'górna część pleców, barki', 'łopatki' i inne. W języku staroczeskim znane były formy plece n., plecě f. (Stčsl), później notowano plece n., pleco n., plec f., plec m. (Jg III 109, Kott II 580), dziś plec f., rzadziej plece n. (PS IV/1, 309, SSJČ II 606), najczęściej w znaczeniu 'górna część pleców nad łopatką', tzn. 'barki’. Podobnie w języku słowackim od XV wieku plece n. (HSSJ III 544-545), w gwarach plece i pleco (SSN II 824-825) głównie w znaczeniu 'górna część pleców', 'barki'. Znaczenia 'plecy', 'tylna strona tułowia od barków do pasa' w tych językach nie znalazłem. Brak tu też formy ${ }^{\star}$ pletji.

Na Białorusi ${ }^{\star}$ pletji w znaczeniu 'plecy' znane są natomiast od dawna. HSBM XXIV 370-371 notuje плечu pl. 'plecy' już pod koniec XV wieku 
(1493) i wielokrotnie w XVI i XVII wieku. Raz pojawia się (w 1621 r.) forma fonetycznie polska на плецахъ (a ponadto w r. 1561 forma polska y плеиу 'na łopatce'). Formę пле́чы w znaczeniu 'plecy' podaje też słownik współczesnego języka białoruskiego (TSBM IV 283).

Znaczenie 'plecy' należy widzieć też w ukraińskich zwrotach датu, показати плечи 'odwrócić się tyłem', 'uciec' przytaczanych w słowniku Tymčenki II 110. Hrinč III 195 i słownik współczesnego języka ukraińskiego (SUM VI 579) nлeчé notują tylko w znaczeniu 'ramię', nie podają też formy плечu.

Forma *pletji w znaczeniu 'plecy' tworzy w OLA też kilka wysp w południowej Słowiańszczyźnie: głównie w dialektach macedońskich (pleki, plešti, pleški, plešči, plefči i i czarnogórskich (plèći i podobnie), ale w rozproszeniu też w Serbii $(68,84)$ oraz w Chorwacji na wyspie Dugi otok (p'leti 37$)$. Nazwa ta ma potwierdzenie w materiałach porównawczych z południowej Słowiańszczyzny, słowniki jednak podają nieco inne znaczenie, a mianowicie 'górna część pleców, barki', ale nie 'plecy'. Słowniki macedońskie nлеќu plt. określają jako 'задниот дел од рамената и горниот дел од грбот' (RMJ II 183, TRMJ IV 112), a bułgarskie nле́mú plt. podobnie jako 'задната част на раменете и горната част на гърба' (RSBKE II 510) lub 'горната част на гърба, която обхваща раменната част и плешките’ (RBE XII 550-551).

W OLA natomiast nazwy ${ }^{*}$ pletji i ${ }^{\star} g$ zrrbz w znaczeniu 'plecy' wykazują dosyć wyraźne zróżnicowanie terytorialne. Nazwę * pletji zanotowano tylko w dialektach macedońskich, zresztą na znacznym obszarze jako wyłączną. Natomiast powszechny w dialektach bułgarskich ${ }^{*} g \not b r b z$ obejmuje w OLA też północną i wschodnią Macedonię, a sporadycznie pojawia się też w jej części środkowej i na terenie północnej Grecji. Nasuwające się podejrzenie, że eksploratorzy OLA nie zauważyli tej różnicy znaczeniowej, jest jednak niesłuszne, bowiem Drvošanov $(2005,76-78)$ potwierdza znajomość nazwy плеќu w dialektach macedońskich w znaczeniu 'plecy'. Według niego плеќu w dialektach macedońskich najpowszechniejsze są w znaczeniu 'górna część pleców', ale także szeroki zasięg mają w znaczeniu 'plecy', a poza tym występują też w znaczeniu 'łopatki'. Wyznaczony przez niego zasięg znaczenia 'plecy' jest dokładniejszy, ale $\mathrm{w}$ zasadzie nie ma tu sprzeczności z danymi OLA.

Natomiast, inaczej niż w OLA, гpб w znaczeniu 'plecy' występuje u niego na całym terytorium macedońskim, lokalnie zaś ma znaczenie 'dolna część pleców' (Drvošanov 2005, 78-79).

Również na terenie serbsko-chorwackim forma *pletji - plëći ma szerokie potwierdzenie w materiałach porównawczych w znaczeniu 'plecy', częściej jednak 'barki, górna część pleców' (RHSJ X 34-35, 37; RSHKJ IV 469), do której została wtórnie dotworzona też rzadka forma liczby pojedynczej pleć ( ${ }^{*}$ pletjb). 
W Polsce zanotowano sporadycznie w dwóch punktach $(259,283)$ obocznie innowacyjną formę plexy, utworzoną od uciętej podstawy ple-za pomocą mającego znaczenie augmentatywne sufiksu - $\chi$.

W południowej Słowiańszczyźnie w znaczeniu 'plecy' zanotowano też formę * pletja, stanowiącą liczbę mnogą od * pletje n. Na mapie oznaczona jest ona na szarym tle kółkiem zaczernionym po prawej stronie. Tworzy złożony z kilkunastu punktów zwarty areał na zachodzie Chorwacji. Zmapowane pod * pletja trzy punkty słoweńskie stanowią arbitralne uproszczenie: w rzeczywistości w p. 19 występuje forma liczby pojedynczej p'lieče ( ${ }^{*}$ pletje n.), a w p.16 i 18 formy liczby mnogiej dotworzone do zapewne wtórnie potraktowanej jako liczba pojedyncza formy ${ }^{\star}$ pletja: plé:če (16) i p'leičce (18), tj. ${ }^{\star}$ pletję. Poza tym formę ${ }^{\star}$ pletja zapisano $\mathrm{w}$ rozproszeniu: w punkcie słoweńskim na terenie Włoch (plé:ča - 2), w Chorwacji na wyspie Dugi otok (p'let́a 37), nad Adriatykiem (pléća 45), w Bośni (pléća - 47), w Wojwodinie (pléća 55) oraz w Serbii (plèća 68, p'leća 69, 81, p'l'eća 84). Formę * pletja - pleca zanotowano też w czeskim atlasie gwarowym w kilku punktach śląskich na pograniczu polskim. Autorzy traktują ją jako plurale tantum wywodzące się z pierwotnej liczby podwójnej (ČJA I 52, s. 147-149).

Forma ta ma potwierdzenie w języku słoweńskim, znów jednak chodzi raczej o 'górną część pleców', a nie o 'całe plecy', por. słwń. pléča n. pl. 'zgornji del človeškega ali živalskega trupa med lopaticama' (SSKJ III 628).

Występujące w języku starosłowiańskim пиєщє 'plecy' raz jest poświadczone w formie liczby podwójnej пмєштн, a czterokrotnie w formie liczby mnogiej пиєшта (SJS III 50).

Na całym wschodzie, jak już wspomniałem, występuje powszechnie ${ }^{*}$ spina. Przyjmuje się, że stanowi ona pożyczkę łacińską, przejętą za pośrednictwem polskim. Przypuszczenie to wysunęli Miklosich (1886, 318; o przyjmowaniu pośrednictwa polskiego świadczy u niego układ materiału) i Brückner (1914, 223; stwierdzając, że pożyczki łacińskie przechodzą do języka rosyjskiego zazwyczaj przez język polski). Brückner (SE 509) pisał: „spina, słowo łacińskie: grzbietowa spina 'plecy', u nas w 16. wieku używane; od nas przeszło na Ruś, gdzie do dziś ogólnie istnieje, gdy u nas o nim całkiem zapomnieli”.

Wyraz ten nie ma ustalonego pochodzenia. W etymologicznych słownikach języków słowiańskich mówi się o możliwości pierwotnego pokrewieństwa tego wyrazu z łot. spina 'pręt', łac. spina 'cierń, kolec', 'grzbiet', stwniem. spinula 'szpilka', tochar. A spin- 'hak, kołek', stang. spir 'długi pęd', śrdniem. spîle 'rożen', nadal jednak przyjmuje się dla języków wschodniosłowiańskich pośrednictwo polskie, por. Vasmer REW (1955) II 708, Vasmer ESRJ III (1971) 735, ESUM V (2006) 371, ESBM XII (2008) 266. Ta jednomyślność w przyjmowaniu 
pośrednictwa polskiego we wspomnianych słownikach musi dziwić, skoro O. N. Trubačev (ESSJP 81) już w 1963 roku stwierdził, że pośrednictwo polskie jest tu mało prawdopodobne („заимствование через польск. из лат. маловероятно, вопреки Миклосичу и Брюкнеру (см. Miklosich 318, Brückner 509). Дату первого русск. свидетельства, приведимого у Фасмера (Аввакум), можно отодвинуть еще на одно столете, см. пример у Срезн. III Доп. 247 [Наказ. Бор. Сев. 1563]"). Zaskakuje fakt, że Trubačev w artykule o tym wyrazie w Vasmera ESRJ III $735 \mathrm{z}$ podania tego zastrzeżenia zrezygnował. Czyżby zmienił zdanie?

Dla rozstrzygnięcia ewentualnego wpływu polskiego na wschsłow. spina 'plecy' należy przede wszystkim przyjrzeć się znajomości tego wyrazu w języku polskim. Brückner, jak wspomniałem wyżej, twierdził, że spina 'plecy' u nas w 16. wieku było używane. Tymczasem w kartotece SP XVI w. znajdujemy tylko jedno poświadczenie tego wyrazu, znane zresztą już z Lindego V 382, mianowicie z łacińskiego dzieła Andrzeja Frycza Modrzewskiego w tłumaczeniu Cypriana Bazylika O poprawie Rzeczypospolitej (Łosk 1577): „Skarb pospolity byłby jako jedna spina abo cięciwa wojny na każdego nieprzyjaciela". Wyrazy spina i cięciwa zostały tu użyte na miejscu łac. belli nervus w trudnym do ustalenia znaczeniu. Linde tłumaczył tu spina jako 'rzecz napięta', M. Korolko $(2003,398)$ objaśnia przez 'strzała', według mnie można też przyjąć 'sprężyna', 'czynnik sprawczy'. Nasuwają się wątpliwości, czy chodzi tu o przenośne użycie wyrazu spina o podstawowym znaczeniu 'plecy', 'grzbiet zwierzęcia lub człowieka'. Zapewne jest to raczej doraźnie użyty homonim, nawiązujący do spinania, napinania. W każdym razie nie można tu dopatrywać się źródła pożyczki dla języków wschodniosłowiańskich.

Spina 'plecy', 'grzbiet zwierzęcia lub człowieka' pojawia się w języku polskim sporadycznie później i to wyłącznie u autorów związanych z Kresami. W kartotece Słownika języka polskiego XVII-XVIII wieku (S XVII-XVIII) znajdujemy kilka poświadczeń tego wyrazu. W Hippice to jest nauce o koniach (Kraków 1603) Krzysztofa Dorohostajskiego, związanego swoją działalnością z Litwą, Białorusią i Wołyniem, trzykrotnie występuje spina grzbietowa 'grzbiet koński’ (jeden z przykładów przytoczył Linde V 382). W rękopisie Archiwum Radziwiłłowskiego pod rokiem 1656 pojawia się raz kość wielka spiny człowieczej. U Hieronima Floriana Radziwiłła (w wydaniu M. Brzeziny, Warszawa 1998) spina poświadczona jest trzykrotnie w znaczeniu 'grzbiet zwierzęcia': „....cielę dwugłowe. Też miało dwa serca i dwie spiny, nóg zaś tylko, jak zwyczaj, cztyry” (s. 33) w Diariuszach z 1747-1751 roku oraz „Zimową tedy porą wziąć trzeba barana i ołupiwszy go do spiny z obydwóch stron...” (s. 207) i „w kark, lecz tak by kość od spiny idąca była przetrącona [u niedźwiedzia]” (s. 211) w Compendium 
z 1740 roku. Późniejsze słowniki języka polskiego nie wnoszą tu nic nowego: SWil II 1536, przytaczając za Lindem przykłady z Dorohostajskiego i z Modrzewskiego (Bazylika), uznaje wyraz spina 'kość grzbietowa'; 'rzecz napięta' za przestarzały i regionalny, a SW VI 294, powołując się na Dorohostajskiego, uważa spina, śpina 'plecy, grzbiet, kręgosłup, stos pacierzowy' za wyraz gwarowy. I to na razie wszystko, co udało się zgromadzić.

Dokumentacja gwarowa tego wyrazu na terenie Polski też jest skromna i dotyczy kilku punktów, głównie na pograniczu wschodnim. MAGP VIII m. 393 w znaczeniu 'grzbiet człowieka i zwierzęcia' ma szpina z p. 58 (Budy pod Bielskiem Podlaskim) oraz spina z przesiedleńczego p. 97 koło Wrocławia. Kartoteka SGPA potwierdza szpina 'plecy' z Bud pod Bielskiem Podlaskim, a ponadto podaje sṕina 'część kręgosłupa na wysokości bioder' ze Sławatycz. Na podstawie kwestionariusza AGWB I 227 można wywnioskować, że šṕin'a 'plecy' odnotowano w Klewinowie (p. 65) $16 \mathrm{~km}$ na południe od Białegostoku. Odpowiedniej mapy w AGWB jednak nie ma. SGPK V 197 ma wreszcie spina 'plecy' spod Augustowa oraz z mało wiarogodnego zbioru słownikowego A. Petrowa z ziemi dobrzyńskiej, gdzie autor zresztą w nawiasie powołuje się na ros. спина.

Materiały dotyczące pol. spina 'plecy', 'grzbiet człowieka i zwierzęcia' wyraźnie zatem pokazują, że wyraz ten ograniczony jest do pogranicza wschodniego i występuje w nawiązaniu do języków wschodniosłowiańskich. Należy go uznać za zapożyczenie ze Wschodu. Słusznie też W. Werenicz (1990, 95) uważa, że w polskim dialekcie na wschód od Pińska s’ṕina, sṕina 'grzbiet zwierzęcia' należy uznać za wpływ białoruski.

W językach wschodniosłowiańskich *spina w znaczeniu 'kręgosłup', 'plecy', 'grzbiet człowieka lub zwierzęcia' poświadczona jest dosyć późno, dopiero w XVI wieku, por. ros. спина w SrezMat III, dop. 247, SRJ XI-XVII, t. XXVII 32, podobnie w języku białoruskim спина 'спіна - grzbiet', 'część grzbietowa ryby' pod koniec XVI wieku (HSBM XXXII 144). Jak się zdaje, w języku ukraińskim pojawia się jeszcze później (nie ma tego wyrazu jeszcze w kartotece SUM XVI-XVII). Znaczenie to w językach wschodniosłowiańskich udokumentowane jest jednak wcześniej niż w języku polskim.

Jak wynika z przedstawionych materiałów, nie ma żadnych podstaw, by przyjmować tu wpływ polski na języki wschodniosłowiańskie. Wpływ odwrotny jest natomiast w pełni możliwy (por. Siatkowski 2013, 36-40).

Formacje ${ }^{*} \chi$ rbbbtz, ${ }^{*} \chi$ ribbtz miały zapewne pierwotne znaczenie 'górna lub dolna część czegoś', a wtórnie jako nazwy części ciała 'plecy’ i/lub 'kręgosłup'. Są one bogato poświadczone w znaczeniu 'plecy' już w języku starosłowiańskim,

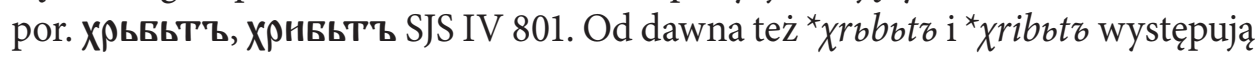


niemal we wszystkich literackich językach słowiańskich w znaczeniu 'plecy' i/lub 'kręgosłup', co podają słowniki etymologiczne, por. np. ESSJ VIII 96-97, 107-109, Bezlaj I 202, Snoj 176, Skok I 685, Vasmer ESRJ IV 274-275, ESUM VI 208-209, Boryś SE 184. Najsłabiej były reprezentowane we wschodniej części południowej Słowiańszczyzny, np. w języku bułgarskim u Gerova V 511 xróbetz 'kręgosłup' i mac. 'pбem 'kręgosłup', 'grzbiet' z jednego tylko źródła. W wielu językach zaczęło dominować znaczenie ogólne 'grzbiet', 'górna lub tylna część czegokolwiek'. W języku rosyjskim dziś xrebét oznacza głównie 'kręgosłup', a w znaczeniu 'plecy' jest przestarzały i pospolity (SSRLJ XVII 454-455).

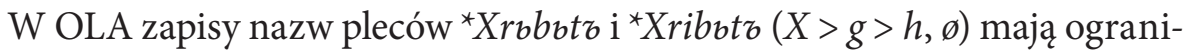
czony zasięg. Tworzą jeden większy zwarty kompleks, obejmujący dialekty łużyckie (zróżnicowanie fonetyczne w gęstszej siatce punktów pokazuje SSA VI 36, s. 108-109), czeskie (řbet, hřbet itp., zasięg i fonetyczne zróżnicowanie nazwy tej w dialektach czeskich dokładniej podaje ČJA I 52, s. 147-149), słowackie ( $\chi_{\circ}$ ba:t,

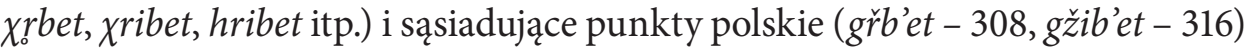

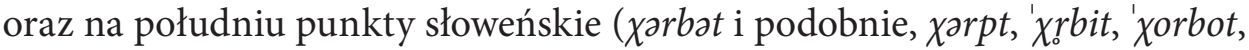
'rbet itp.), a także łączące oba zespoły wyspowe dialekty słowiańskie na terenie Austrii i Węgier. Pozostałe zapisy są rozproszone: w Czarnogórze (ŕbạt - 77), w Serbii (ŕ:bat - 79), w Polsce na Kaszubach (křept - 241) i na Śląsku ( $g z ̌ b ’ o t$ - 269), na Białorusi (hrb'b'et - 337), na Ukrainie Zakarpackiej ( $\chi \mathrm{rbl} b e t-484$ ) oraz w Rosji pod Nowogrodem ( $\chi r^{\prime} e^{\prime} b$ 'ot - 635).

Podstawa słowotwórcza omawianego derywatu ${ }^{*} \chi r b b r,{ }^{\star} \chi r i b r$, zanotowana w OLA w kilku punktach w południowej Rosji ( $\chi r^{\prime} i p-791,806, \chi r^{\prime} i b-813$ ), ma potwierdzenie $w$ materiałach porównawczych właśnie znad Donu, por. ESSJ VIII 96 s.v. * $\chi$ ribr.

Również sporadycznie zapisana na Białorusi pod Szczuczynem (344) * $\chi$ ribetina - xri'b'ac'ina ma potwierdzenie w SłPogr V 325 z tych stron: spod Szczuczyna, Grodna i Nowogródka (хры'беціна, хрь'бяціна), a ponadto na Ukrainie хребети́на, хребти́на (ESUM VI 208 s.v. хребет), znana zresztą już w XV wieku (хребтїна - SSUM II 517) oraz w dialektach rosyjskich (хребти́на, хребети́на - Dal IV 565).

Nazwy 'pleców' związane z rdzeniem * gzorrb- zapisano w OLA głównie we wschodniej części południowej Słowiańszczyzny. Występują one w kilku zróżnicowanych terytorialnie postaciach. Podstawową formę ${ }^{*}$ gzr rbz notowano w całej niemal Bułgarii (grəp, gərp, gạp, grp) i w znacznej części macedońskiego obszaru dialektalnego, a ponadto w zupełnej izolacji w polskim p. 259 jako augmentativum garby. W dialektach macedońskich ma ona zresztą szerszy zasięg, niż to wynika z zapisów w OLA. Drvošanov $(2005,78-79)$ bowiem, rozporządzając znacznie bogatszym materiałem zebranym w gęstszej siatce punktów, stwierdza 
mianowicie, że ${ }^{\star} g \underset{r b r}{ }$ (grb, grp, garp itp.) w znaczeniu 'plecy' znany jest na całym terytorium gwar macedońskich. Poza tym w kilkunastu punktach zapisał on ten wyraz także w znaczeniu 'dolna część pleców, krzyże'. Powszechną znajomość wyrazu ${ }^{\star} g$ zrrbz w znaczeniu 'plecy' na terenie bułgarsko-macedońskim potwierdzają też słowniki tych języków, por. bułg. гръб(ъ) m.in. 'plecy' u Gerova I 250-251, w RSBKE I 208, RBE III 423-428, BTR 147 i w gwarach (por ESSJ VII 199-201, SP III 273-274), mac. гp6 'ts.' (RMJ I 114, TRJM I 373).

Wyraz ${ }^{\star} g$ grbr w znaczeniu 'plecy’ w materiałach porównawczych pojawia się też sporadycznie na gruncie serbsko-chorwackim, por. serb. $2 \hat{p} 6$ 'plecy' z Prizrenu w Kosowie i z nieustalonego źródła (RSHJ III 583-584, tu nieobjaśniony skrót $U$ - zapewne słownik), poza tym w zabytku cerkiewnym z XVI-XVII w. gə̧rbz 'grzbiet ryby' (RHSJ III 391) oraz w języku słoweńskim: chodzi tu o hasło u Pleteršnika I 246, gdzie pod gr̂rb jest odsyłacz do grba f. 'garb', 'plecy', 'zmarszczki'. Nie podano jednak, które ze znaczeń formy grba odnosi się również do formy gr̂rb. SP VIII 273-274, powołując się na Pleteršnika, podaje tylko znaczenie 'garb', natomiast ESSJ VII 199-201 na podstawie podobnych źródeł wymienia wszystkie trzy znaczenia. Jak się zdaje, sprawę rozstrzyga Bezlaj I 172, który pod hasłem gŕba umieszcza z XVI wieku z Dalmatina gerb w metaforycznym znaczeniu 'plecy'.

Wspomniana wyżej forma żeńska * gžrba, nienotowana w OLA w ogóle, też jest sporadyczna w znaczeniu 'plecy': słwń. gŕba 'plecy' podaje Plet I 246, a jako ekspresywne także SSKJ I 751: mahnil ga je po grbi 'uderzył go po plecach, w plecy', a sch. грбба 'plecy' RSHJ III 585: турски изаринари и заптије изредали се да исправе грбе и да поздраве z r. 1888.

Okazuje się, że ${ }^{*} g \not z r b r$ w pewnych potocznych zwrotach pojawia się w metaforycznym znaczeniu 'plecy', 'grzbiet' w wielu dalszych językach słowiańskich, por. np. dostat, dát do hrbu 'dostać, uderzyć po plecach' (PS I 962, SSJČ I 646, też w gwarze morawskiej - ESSJ VII 200), słc. dial. dostat po hrbe, daj mu po hrbie 'daj mu po grzbiecie, po plecach', brus. pot. ekspr. горб 'plecy, grzbiet' (TSBM II 70), dial. у вайну маткі дзеиі няслі на гарбах (SłPogr I 465), ukr. pot. горб 'plecy, grzbiet' z I połowy XVII wieku (SUM XVI-XVII, t. VII 21) i współcześnie np. гнýmu горбá 'usilnie pracować' (SUM II 125), ros. горб 'plecy’ już z XIII i XVI w. (SRJ XI-XVII, t. IV 80) i później (SRJ XVIII, t. V 166, Dal I 377-378) oraz współcześnie w zwrotach ze znaczeniem 'schylone, zgarbione plecy', 'plecy, na których niesie się coś ciężkiego', jak np. гнymb горб 'zginać grzbiet, ciężko pracować', на своим горбу нести 'nieść na swoim grzbiecie, na swoich plecach', на горбу сидеть у кого-л. 'siedzieć komu na plecach' itp. (SSRLJ III 269-270, BASRJ IV 287-288), a nawet w gwarach nad Peczora (ESSJ VII 200; SRNG znaczenia tego jednak nie odnotował). 
W sumie można powiedzieć, że ${ }^{*}$ gørbr w pewnych zwrotach w znaczeniu metaforycznym 'plecy, grzbiet' znany jest niemal w całej Słowiańszczyźnie, natomiast w podstawowym znaczeniu części ciała 'plecy' tworzy zwarty areał tylko we wschodniej części Słowiańszczyzny południowej.

Od zachodu z tym areałem sąsiaduje formacja rozszerzona sufiksem -ina - ${ }^{*}$ garbina, zapisana w OLA w dwóch punktach na zachodzie Bułgarii (gr'bina 115, gar'bina 118), w dialektach serbskich ( gr'bina 79, 81, 83, 85-88) oraz w rumuńskim

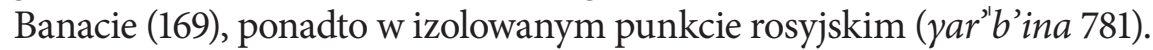

Nazwa грьбина 'plecy' ma bogate potwierdzenie w RSHJ III 588 w dwudziestowiecznych utworach wydawanych w Belgradzie, natomiast zagrzebski RHSJ III 394 uważa gr̉bina za wyraz nieco przestarzały. Bułg. гръби́на 'plecy' przytacza już Gerov I 250, ale późniejsze słowniki przypisują tej nazwie zabarwienie potoczne (RSBKE I 214, RBE III 487-488, BTR ${ }^{4} 150$ ). W języku macedońskim грбина 'plecy' została uznana za wyraz gwarowy (RMJ I 114), który TRMJ zupełnie pomija. Por. też ESSJ VII 199, SP VIII 271-272. Na gruncie wschodniosłowiańskim potwierdzenia dla tego wyrazu nie znalazłem.

Formację * gzrrbača w znaczeniu 'plecy' zapisano w OLA na południu tylko w kilku punktach: w Bośni (gŕbača 47) oraz w Serbii (grbača 69, 81). W RSHJ III 587 гpбачa uznana jest za wyraz ekspresywny (podobnie uważa Skok I 610) i ma dosyć bogate poświadczenie zarówno z utworów chorwackich, jak i serbskich, natomiast zagrzebski RHSJ III 392 podając gr̀bača w znaczeniu 'plecy', powołuje się tylko na Vuka, natomiast współcześnie przypisuje temu wyrazowi znaczenie 'kręgosłup'.

Zupełnie odosobnione są występujące $\mathrm{w}$ gwarach rosyjskich formacje: gorbaz'ina ( ${ }^{*}$ gorbazina) - 588 i jarbat'ina $\left(^{*}\right.$ gorbatina) - 786. Ich potwierdzenia $\mathrm{w}$ materiałach porównawczych nie znalazłem.

Forma *lędvoje miała dawniej szeroki zasięg w Słowiańszczyźnie. Najczęściej oznaczała 'część pleców po obu stronach kręgosłupa między żebrami a miednicą', 'lędźwie', 'biodra', nieraz też inne przyległe części ciała. Pełniejsze zestawienia w tych różnych znaczeniach można znaleźć w słownikach etymologicznych, por. np. ESSJ XV 48-50, ESJS VIII 418. W OLA zapisywano *lędvbje i pochodne w znaczeniu 'nerka' (Siatkowski 2012a, 274-276) oraz kilka wyrazów pochodnych w znaczeniu 'udo' (Siatkowski 2012a, 184). W znaczeniu 'plecy' zapisywano w OLA zazwyczaj formę liczby mnogiej ^lędVıja $(V>\emptyset)$ : lé:źa, lè:źa, lè:đa itp.), co tworzy dosyć zwarty areał na terenie serbsko-chorwackim, z którym łączy się kilka punktów wyspowych na terenie Węgier (lè: $\mathfrak{d} a-150$, le:đa - 151, lé:źa 152) i we wschodniej Austrii (lièd’e tu sg. - 146a).

Nazwa 'pleców' ${ }^{\star} z a d a$ ( $\left.z a: d a\right)$ charakterystyczna jest dla dialektów czeskich. Występuje ona niemal na całym czeskim terytorium językowym obocznie z na- 
zwą ${ }^{\star} \chi$ rbbbtz (por. wyżej, s. 6). Dokładniej zasięgi obu tych nazw w dialektach czeskich przedstawia ČJA I 52, s. 147-149. U nas nie ma jej tylko na czeskim Śląsku, a w ČJA także na wschodnich peryferiach dialektów wschodniomorawskich. Według ČJA hřbet obecnie ustępuje przed nazwą záda, zwłaszcza w mowie miast, a w szczególności na Morawach i na terenach nowego osadnictwa w Czechach. W związku z tym tylko jako ciekawostkę należy potraktować rozróżnienie Kotta: „Záda mají hřbet (dorsum, krajinu zád prostřední nad celou hrudní pateří), meziplecí (interscapuleum, místo mezi lopatkami), zadek (uraeum, meziplecí až k řiti), bedro (regio lumbalis, naproti břichu), kř́žz (regio sacralis, od beder až k řiti)" (Kott V 34). W gwarach czeskich są to niewątpliwie nazwy synonimiczne. Czeska nazwa záda wywodzi się z ogsłow. rzeczownika ${ }^{\star} z a d z$ 'tylna część, tył', utworzonego od przyimka $z a$ za pomocą sufiksu - $d$ z (por. np. Machek ES-2, 708; Boryś SE 725). Pierwotne zad m. sg. przeszło w plurale tantum na wzór takich nazw, jak prsa 'piersi', bedra 'biodra'. W języku staroczeskim w znaczeniu 'plecy' wcześniej używano formy genetycznie deminutywnej zadek (MSČS 624), ale w XVI wieku u Veleslavína już obok zadek występuje też forma záda (Jg V 445, 446; Kott V 34-35). Z czasem w znaczeniu 'plecy' upowszechniają się záda, a zadek przybiera znaczenie 'podex, tyłek'.

Nazwę zad m., záda plt. dla 'pleców' odnotował też historyczny słownik słowacki: z XVII-XVIII wieku (HSSJ VII 25), ale podany tu zestaw przykładów ze słowackiego tłumaczenia J. A. Komenskiego, z zachodniej Słowacji i jeszcze jednego trudnego do zlokalizowania zabytku, przy podanym wyżej braku tego wyrazu w dialektach czeskich na Śląsku i na wschodniej peryferii dialektu wschodniomorawskiego, wydaje się przemawiać za możliwością wpływu czeskiego. Współczesny słownik słowacki SSJ już tego wyrazu nie notuje.

Pozostałe rodzime nazwy 'pleców', zanotowane w OLA, są rzadkie lub zupełnie sporadyczne. Przeważnie stanowią doraźne przeniesienie semantyczne nazw odnoszących się głównie do 'górnej lub dolnej części pleców’, przeniesienie to ma jednak często potwierdzenie w materiałach porównawczych.

Zapis gri: $n^{e}$ w punkcie chorwackim na południu Włoch (44a) należy zapewne uogólnić jako *grivınja. W sch. grî́ija, grîna, grina oznacza 'sznur pereł', 'wieniec z fig' (RHSJ III 432-434). Skok I 620 skłonny jest widzieć pierwotne znaczenie 'kark'. Mielibyśmy tu do czynienia z przeniesieniem znaczenia 'barki' > 'plecy'.

Zanotowane obocznie z nazwą plecy w Polsce pod Złotowem (249) i pod Poznaniem (259) bary są późną, XIX-wieczną, innowacją polską, stanowiącą augmentativum od mającego szersze nawiązania słowiańskie wyrazu barki, znanego wcześniej w języku polskim w znaczeniu 'silnie rozrośnięte ramiona', 
'górna część pleców poniżej karku' (SW I 101, SJPD I 362-363, Brückner SE 16-17, Boryś SE 22). Bary w znaczeniu 'silnie rozrośnięte ramiona' znane są też gwarom polskim (SGPA I 412-413).

Zapisany na Zakarpaciu po'perek ( ${ }^{*}$ popererk - 483) oznacza częściej w języku ukraińskim 'dolną część pleców', 'krzyż, lędźwie', por. Hrinč III 323, SUM VII 191, por. też ros. z XVII w. поперекъ 'ts.' (SRJ XI-XVII, t. XVII 80).

Brus. 'tułov'išče, tuło'v'išče 'plecy' na zachodzie kraju (363) wykazuje przesunięcie znaczeniowe wobec występującego we wsch. Słowiańszczyźnie wyrazu *tulovišče w znaczeniu 'tułów', por. ros. i ukr. mýловище (SSRLJ XV 1114-1115, ESUM V 672) i brus. dial. ту́ловишча (SłPogr V 145), ту́лобішчэ (ESUM V 672).

Zapisana obocznie ze s'p'ina pod Briańskiem (798) s'e'r'ad'ina ( ${ }^{*}$ serdina) ma potwierdzenie w rosyjskim słowniku gwarowym spod Smoleńska (сере́дина 3. 'спина' - SRNG XXXVII 201-202), a także w dialektach białoruskich (ESBM XIII 156). Wyraz ten częściej notowany jest w znaczeniu 'dolna część pleców', a mianowicie u Dala IV 176-178, a w SRNG l.c. z dialektów spod Briańska, Orła i Smoleńska. Poza tym сярэ́dзіна w znaczeniu 'dolna część pleców', 'krzyż, lędźwie’ znana jest powszechnie na Białorusi. Podaje ją TSBM V/1, 452, uznając to znaczenie za potoczne. Według Čekmana 1972, 151 сярә́дзіна występuje w tym znaczeniu na całym białoruskim terytorium językowym, może jedynie poza Polesiem (por. też lokalizację w ESBM l.c. i w SłPogr V 72, także z gwar białoruskich na terenie Polski i Litwy). Čekman l.c. ze względu na wyjątkowe w dialektach słowiańskich połączenie znaczenia 'dolna cześć pleców, krzyż ze 'środkiem' widzi tu wpływ podobnie motywowanej litewskiej nazwy pusiáujas dla tej części pleców. Nie jest to konieczne, skoro znana jest analogiczna bułg. i mac. половина, łącząca się z 'połową'.

Zanotowana w płn.-zach. Białorusi nazwa 'z'atn'a 'kostka (338) ma potwierdzenie właśnie z tych stron w SłPogr II 337 ('зятняя 'костка). Może chodzi tu o metaforyczne określenie - 'zięciowa kosteczka', 'kostka zięcia' (D.K. Rembiszewska).

Nie umiem wyjaśnić sporadycznego zapisu ko'ri:s w Czarnogórze (73).

W materiałach OLA jest także kilka, zazwyczaj rzadkich, nazw 'pleców' obcego pochodzenia, częściowo są to nazwy przeniesione, odnoszące się częściej do części pleców lub kręgosłupa.

Nieco szerszy zasięg ma nazwa ${ }^{\star}$ skinJa $(J>\emptyset)$, zanotowana w Dalmacji na wyspach Krk (ški:na - 24), Vis (skki:na - 42) i Hvar (ški:ńa - 44) oraz na Wybrzeżu Dalmatyńskim w Trogirze (ski:na - 43). Według Skoka III 259 jest to relikt dalmatyńsko-romański pochodzenia germańskiego (z dawnego skǐna, kontynuowanego przez nwniem. Schiene 'szyna'). Pożyczka ta, poświadczona 
na terenie serbsko-chorwackim od XVI wieku w znaczeniu 'plecy' i 'kręgosłup' (RHSJ XVII 657), ma według Skoka l.c. szerokie nawiązania w Dalmacji, zarówno na wyspach, jak i na wybrzeżu.

W rozproszeniu w różnych częściach Słowiańszczyzny zapisano w OLA w znaczeniu 'plecy' przejętą do języków słowiańskich za pośrednictwem

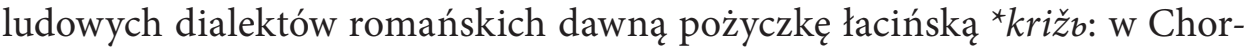
wacji kri:ža obok ški:na i ple'ta (24), w punkcie słoweńskim w południowej Austrii Prí:̌̌ (148), w Polsce pleci obok kšiže (250) i plecy obok kšyš (300) oraz na Ukrainie Zakarpackiej p'lyč i obok kry'ža (465). Mamy tu do czynienia z przeniesieniem znaczenia 'plecy' z częstszego w językach i dialektach słowiańskich znaczenia 'dolna część pleców', 'dolna część kręgosłupa' (liczne poświadczenia tego znaczenia podaje Sławski SE III 256-258). Dotyczy to też

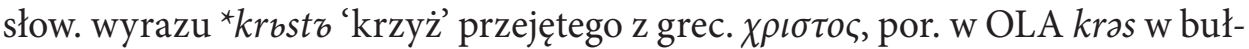
garskim punkcie na terenie rumuńskiego Banatu (167) i w bułgarskim języku literackim $\kappa$ рғст (RBE VIII 295, BER III 50-56) oraz serbsko-chorwackiego

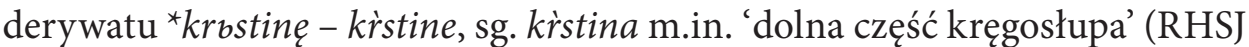
V 640, RSHJ X 668), zapisanego sporadycznie w OLA w znaczeniu 'plecy' w chorwackim punkcie na terenie rumuńskiego Banatu (krs'tine - 168). Podobne przesunięcie znaczeniowe znane jest zresztą nie tylko językach słowiańskich (por. Sławski l.c.).

Sch. kîčma (od tur. kıç 'tylna część', 'pośladek', por. Škaljić 407, Skok II 77), zapisana w OLA w dwóch punktach bośniackich: kì:čma (46) i kičma (57) w znaczeniu 'plecy', znana jest od XVIII w. w znaczeniu 'kręgosłup' (RHSJ IV 944, RSHJ IX 522). Pojawiające się nieraz na terenie serbsko-chorwackim znaczenie 'plecy' uważane jest za regionalne (RSHJ l.c.).

Zapisana zupełnie sporadycznie pod Woroneżem kəba'roškə ma potwierdzenie w rosyjskim słowniku gwarowym właśnie spod Woroneża (кабаро́жка SRNG XII 283). Jest to derywat od кабарza z turk. kabyrya 'żebro' (Vasmer ESRJ II 149).

\section{ramię}

Nazwy 'ramienia' dzielą Słowiańszczyznę na częściowo dosyć zwarte dwa areały: w jednym związane są z rdzeniem ${ }^{\star}$ pletj-, w drugim z rdzeniem ${ }^{\star}$ ormFormy od ${ }^{\star}$ pletj- łącznie zajmują znaczne terytorium, tworząc zwarty kompleks w całej Słowiańszczyźnie wschodniej, do którego nawiązuje obszar dialektów słowackich i kilka punktów czeskich, poza tym w rozproszeniu występują na zachodzie Słowiańszczyzny południowej. Formy od rdzenia ${ }^{\star}$ orm- występują 
zaś w Słowiańszczyźnie zachodniej (z wyłączeniem dialektów słowackich) i południowej.

Od rdzenia ${ }^{*}$ pletj- zanotowano kilka zróżnicowanych geograficznie form rodzajowych, jak ${ }^{\star}$ pletjE $(E>o)$ n., ${ }^{\star}$ pletja f., ${ }^{*}$ pletje pl., ${ }^{\star}$ pletji pl. oraz kilka formacji słowotwórczych, jak ${ }^{\star}$ pletjoko, ${ }^{\star}$ pletjokr, ${ }^{\star}$ pletjukr, ${ }^{*}$ opletjoko, ${ }^{\star}$ opletjbka, ${ }^{*}$ opletjbkr itd. Na mapie cały obszar z formami od tego rdzenia został oznaczony szarą plamą (jak i nazwy od tego rdzenia na mapie 'pleców'), a poszczególne formy fleksyjne i słowotwórcze za pomocą różnie wypełnionego kółka na szarym tle. Jeśli forma ta występuje obocznie z ${ }^{\star}$ pletjE, znak na mapie został podkreślony. Ze względu na brak informacji o rodzaju i liczbie niektóre zapisy, zwłaszcza sporadyczne, trudno zinterpretować. Pewnych form słoweńskich komisja narodowa jednoznacznie nie określiła.

W południowej Słowiańszczyźnie rozproszone zapisy występują w dialektach słoweńskich i chorwackich. Najczęściej notowano tu formę n. sg. ${ }^{*}$ pletjE: w punktach słoweńskich we Włoszech (pliečía nom. pl. od ${ }^{*}$ pletje - 3) i w południowej Austrii (plèča - 148) oraz w kilku punktach chorwackich: w Dalmacji (pletée - 22, 42, plẽ:te - 43) i na północy (plậ:če - 35, pléće - 36). Dla kilku punktów słoweńskich przyjęto formę liczby mnogiej ${ }^{\star}$ pletję pl.: p'lieči (3), plé:če $(7,9), p^{\prime} l \varepsilon: \check{c} \varepsilon$ (17). Zgodnie z uogólnieniem komisji słoweńskiej formę * pletja przyjęto dla dwóch punktów słoweńskich: p'le:ča $(15,149)$, ale nie ma pewności, czy chodzi tu o formę rodzaju żeńskiego w liczbie pojedynczej, czy może o liczbę mnogą od formy rodzaju nijakiego * pletje. Zupełnie sporadycznie zapisano formę rodzaju męskiego ${ }^{\star}$ pletjo w chorwackiej wyspie językowej na południu Włoch plẹčc (44a). Formę ${ }^{\star}$ pletji pl. w znaczeniu 'plecy' na południu zanotowano wyjątkowo w Dalmacji na wyspie Dugi otok (p'let́i - 37). Może należy tu zaliczyć też formę p'liečci (3), zinterpretowaną w OLA jako forma liczby mnogiej ${ }^{\star}$ pletje, por. wyżej.

Ciekawe jest porównanie poświadczeń form ${ }^{\star}$ pletje, ${ }^{\star}$ pletję $\mathrm{w}$ dialektach słoweńskich w OLA i w słoweńskim atlasie językowym. Okazuje się, że powtarza się tylko jeden zapis z punktu 149 na terenie Węgier. Pozostałych zapisów OLA w odpowiednich punktach atlasu słoweńskiego nie ma. Zapisano natomiast, traktowane łącznie, ${ }^{\star}$ pletje i ${ }^{\star}$ pletję $\mathrm{w} 12$ punktach innych: w centrum koło m. Škofja Loka, na zachód od m. Celje, na terenie południowej Austrii, przede wszystkim zaś w 8 punktach na pograniczu węgiersko-austriackim na północ od Murskiej Soboty. Układ ten wydaje się wskazywać, że mamy tu do czynienia z archaizmem, który na południowym zachodzie Słowiańszczyzny miał dawniej szerszy zasięg.

W języku starosłowiańskim плєщє n. ma bogate poświadczenia w znaczeniu 'ramię, 'bark', a formy пиєтн, пкещаa, jak podałem już wyżej, oznaczają 
'plecy' (SJS III 50). Dla słwń. pléče n. znaczenie 'ramię, 'bark' notuje Plet II 54, natomiast w liczbie mnogiej słwń. plêča odnoszą się do 'górnej części pleców

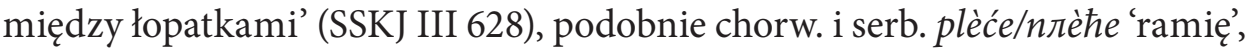
'bark', 'горњи део леђа од врата до руке' (RHSJ X 35, RSHKJ IV 469-470), ale też 'plecy' (RSHJ l.c.).

Na północy Słowiańszczyzny nazwy związane z rdzeniem * pletj- tworzą zwarte kompleksy. Tu również największy zasięg ma forma n. sg. ${ }^{\star}$ pletjE, występująca w dialektach wschodniosłowiańskich (np. brus. pl'a'čo, ukr. płéče, ply'če, ros. pl'éč́o, pl'e'c'o, pl'i'čo itp.), słowackich (pleco, plece itp.) i w trzech punktach czeskich (plece - 204, pleco - 205, 207).

W języku białoruskim плячó (плечо, плече, плеце od XV wieku - HSBM XXIV 370-371) oznacza zarówno 'bark, część tułowia od szyi do ręki', jak i 'górną część ręki do łokcia', a w liczbie mnogiej nлечbl 'plecy' (TSBM IV 283), podobnie w języku ukraińskim nлечé (плече, плечо od XVI wieku - kartoteka SUM XVI-XVII) 'bark, część tułowia od szyi do ręki' i 'górna część ręki' (SUM VI 579-580). W języku rosyjskim występowała staroruska forma cerkiewna плеще, плеште od XI wieku oraz forma rodzima плечо, плече od XII wieku w znaczeniach 'ramię, bark, górna część tułowia od szyi do ręki', w liczbie mnogiej 'część pleców między łopatkami, barki' oraz 'górna część ręki powyżej łokcia' (SRJ XI-XVII, t. XV 92, 93 oraz SSRLJ IX 1395-1396, BASRJ XVII 73-74). W języku słowackim plece n. 'bark, część ciała nad łopatką między barkiem a początkiem ręki' notowana jest od XVI wieku (HSSJ III 544-545, por. też SSJ III 86), a słowacki słownik gwarowy plece i pleco n. w tym znaczeniu uznaje za powszechne w dialektach słowackich.

W południowych dialektach rosyjskich forma ${ }^{*}$ pletje zachowując pierwotną postać, przybiera w kilku punktach rodzaj żeński: pl'a'č́o, pl'a'šo f. (802), pl'a'čo f. (834, 841, 846), pl'ẹ'čo f. (844), pl'e'čom f. instr. sg. (848), a w kilku punktach sąsiednich przybiera rodzaj żeński oraz zakończenie na -a: $p l^{\prime} i^{\prime} c^{\prime \prime} a$ $(839,845)$, pl'e'ča $(840)$. Na mapie zasięg występowania rodzaju żeńskiego został oznaczony za pomocą płaszczyzny.

Na pograniczu polsko-białoruskim w OLA zachodni zasięg formacji od rdzenia * pletj- pokrywa się ściśle z granicą państwową. Źródła porównawcze pokazują jednak, że granica ta nie jest tu ostra: po obu stronach znane są lub były jeszcze niedawno znane nazwy od rdzenia ${ }^{\star}$ pletj- i ${ }^{\star}$ orm-. Tu zwrócę uwagę na występowanie form od rdzenia ${ }^{\star}$ pletj- po stronie polskiej, a wypadki odwrotne przedstawię później.

W AGWB V 27, s. 72 na terenie Białostocczyzny mają szeroki zasięg liczne formacje od rdzenia ${ }^{\star}$ pletj-, przedstawione zresztą na mapie w sposób bardzo uproszczony, nieraz jednym znakiem postaci morfologicznie bardzo różne. Formy 
pleč́e, pleč́o (i podobne) zanotowano tu w szerokim pasie wschodnim, który nad Narwią sięga daleko na zachód, niemalże aż do miejscowości Łapy.

Na pograniczu polsko-ukraińskim formy od rdzenia * pletj- w OLA sięgają do samej granicy polskiej, co potwierdzają materiały Ziłyńskiego, gdzie stosunkowo rzadkie na tych terenach nлечé, pl. nле́чi w znaczeniu 'ramię' notowano jednak i nad granicą polską, a nawet po polskiej stronie w Machnowie koło Tomaszowa Lubelskiego (SDUP 97).

Formę * pletji pl. w znaczeniu 'ramiona' zapisano w kilku rozproszonych punktach: na południu Białorusi ( $\left.p^{\prime} \nmid e c ̌ b l-382\right)$, na Ukrainie ( $\left.p^{\prime} ł e ̨ c ̌ y-433\right)$ i w kilku punktach rosyjskich: p'l'ec'i (554), pl'e'č'i (670) i p'l'eč'i $(764,765)$.

Na wschodzie, głównie na Białorusi i Ukrainie, a nieraz także w Polsce na Białostocczyźnie zanotowano kilka dalszych derywatów związanych z rdzeniem *pletj- w znaczeniu 'ramię'.

Formacja *pletjbko 'ramię' tworzy niewielki areał na terenie łączącym płd.-zach. Białoruś (płyč́ko - 361, pl'ečko - 363, plbıč'ko - 372) i płn.-zach.

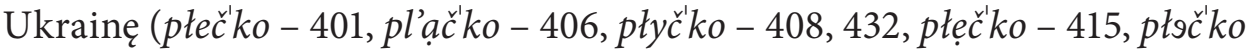
- 452. Do areału tego nawiązują 3 zapisy na Białostocczyźnie: pl'ečko (Topolany ok. $25 \mathrm{~km}$ na południowy wschód od Białegostoku), plečk'o (Teremiski) i pl'ičko (Policzna) koło Hajnówki (AGWB V 27, s. 72). Kartoteka SGPA ma dalsze przykłady na plečko 'ramię' z pogranicza po stronie polskiej z Bud pod Hajnówką, z Dorohuska chełmskiego i z Horodyszcza pod Włodawą. Forma ta ma też potwierdzenie w słownikach, por. brus. плечкó, пльчко́ 'ramię' w ESBM IX 251-252 (bez lokalizacji), ukr. плíкó jako deminutivum od nлечe 'ramię' (Hrinč III 195, 197; SUM VI 527), znane też w innych znaczeniach.

W ukraińskim punkcie na Białorusi (373) zanotowano sporadycznie dalszy derywat ${ }^{*} o p l e t j b k o-o p$ 'l' ičko, który występuje też na Białostocczyźnie w 6 nadgranicznych punktach między Czarną Hańczą a górną Biebrzą: aplečko, apl'éčko. Ponadto na Białostocczyźnie w 2 punktach na południe od Bielska Podlaskiego zapisano *søpletjъko - spl'éčko, spl'厃̂̀čko (AGWB V 27, s. 72).

Zanotowana $\mathrm{w}$ kilku punktach na środkowej Białorusi formacja ${ }^{\star}$ pletjukr - pl'a'čuk (355, 365-368) znana jest właśnie z okolic Mińska w tym znaczeniu też z innych źródeł: SłPogr IV 27 i ESBM IX 251-252 s.v. nлячó, nлечó oraz плячи́к. Poza tym sporadycznie zanotowany w SłPogr IV 27 nad górnym Niemnem плячáк (*pletjøkъ?) ma kilka poświadczeń na Białostocczyźnie: pleč́ak w 3 punktach na południe od Białegostoku i pl'ečok nad górną Narwią w pobliżu granicy. Ponadto na Białostocczyźnie zapisano dalsze prefiksalne derywaty (utworzone zapewne od wyrażeń syntaktycznych z przyimkami na i o): na południu w 3 punktach wzdłuż Bugu w pobliżu Siemiatycz ${ }^{\star}$ napletjøks - napl'ečok, napličok oraz na północy w 3 punktach koło Dąbrowy Białostockiej 
${ }^{*}$ opletjbkr - apl'ecak, opl'écak, opl'éčok (formy z $c<{ }^{\star} t j$ są tu zapewne dawne i nie tłumaczą się mazurzeniem).

Dla zapisanych sporadycznie *opletjoka - op'l'ička (423) na Wołyniu oraz *popletje - pop'l’eča na północy Rosji (551) nigdzie nawiązań nie znalazłem.

Formy od rdzenia *orm-, jak już wspomniałem wyżej, występują w Słowiańszczyźnie zachodniej i południowej. Formy pochodne od tych rdzeni wykazują znaczne zróżnicowanie pod względem morfologicznym, które też tworzą dosyć wyraźne kompleksy. Na mapie zostały one oznaczone szrafowaniem różnego typu.

Dotyczy to form * orme n., ${ }^{*}$ ormo n., ${ }^{*}$ ormeno n., ${ }^{*}$ orma f., ${ }^{*}$ ormenb, a także ${ }^{\star}$ orm $b=o$ (jeśli uwzględnić też źródła spoza OLA). Nieraz zapisano tylko formy liczby mnogiej, które pozwalają na rekonstrukcję liczby pojedynczej. Pomijam natomiast dodatkowe zapisy liczby mnogiej. Poza tym występuje tu wiele ich dalszych przekształceń, które trudno dokładnie określić ze względu na brak w OLA form zależnych lub form liczby mnogiej. Cechą charakterystyczną są występujące wyspowo lub obocznie formy sporadyczne, które pojawiają się często na bardzo odległych terenach. Powstały one w dużym stopniu niezależnie jako formacje potencjalnie możliwe w języku. Ich znajomość na tych terenach potwierdzają materiały porównawcze $\mathrm{z}$ opracowań dialektologicznych i ze słowników, które zresztą często przynoszą jeszcze dalsze nazwy sporadyczne.

Za formy podstawowe od rdzenia * orm-, od których kolejno powstały inne, należy uznać ${ }^{\star}$ ormę i ${ }^{*}$ ormo. Jaki jest ich stosunek wzajemny? W słownikach etymologicznych podawana są one obocznie (Snoj 522, ESUM V 22), częściej ze względu na analogie w innych językach indoeuropejskich za pierwotną uznaje się *ormo (z sufiksem -mo-), a formę * ormę (z sufiksem -men-) za innowację słowiańską (Machek ES-2, 507; Skok III 105-106; Bezlaj III 149; Schuster-Šewc III 1205; SJS XII 747; Boryś SE 510), ale BER VI 175-178 i ESBM XI 88 jako prasłowiańską wymieniają tylko *ormę.

Boryś SE 510 i Skok III 105-106 rdzeń *orm- uznają za ogólnosłowiański, tymczasem w OLA derywaty od tego rdzenia ograniczone są w zasadzie do Słowiańszczyzny południowej i zachodniej. Ich wschodni zasięg niemal pokrywa się ze wschodnią granicą państwową Polski.

Jedynie na Ukrainie nad Dniestrem, głównie na północ od tej rzeki, występuje rozległa wyspa, dochodząca aż pod Horodok (w OLA p. 472), z nazwami od rdzenia *orm-: *ormeno n. ('ramy'no 421, 429, 'rameno 428, 'rams'no 431, 451, 471), *ormens m. ('ramyn 412, 'ram'in' 420) i *ormę n. ('remn'a 472, w OLA zinterpretowane błędnie jako *ormenbja).

Istnienie tej wyspy na zachodniej Ukrainie potwierdzają dawne materiały Ziłyńskiego z licznymi zapisami form р'ам'ен'о, рам'но, рем'ино, р'еміно, 
рьмін'о, римйоно z dialektów ukraińskich na terenie Polski, z szerokiego pogranicza polsko-ukraińskiego, a nawet ją rozszerzają dzięki punktom na południe od Stanisławowa (Jasień, Horodenka) oraz z kilkoma zapisami form рамйа і рамн'a spod Sambora i Drohobycza oraz z dialektów ukraińskich na terenie Polski, m.in. pl. paмн'ér'a w Brylińcach pod Przemyślem (SDUP 97, por. też Horbač 1969, 161; Hrinč IV 5). Tymčenko II 266 obok fonetycznie polskiego рамье ma też рамо. W kartotece SUM XVI-XVII w znaczeniu 'ramię' najczęściej występuje paмA - рамя, ale dwukrotnie z r. 1641 i 1650 pojawia się, ze względu na zakończenie wskazująca na wpływ polski, forma paмe, też z XVII wieku dwukrotnie formy рамено і рамене (jeden z przykładów на раменю своемъ mоże ewentualnie wskazywać na rzeczownik rodzaju męskiego раменъ). SUM VIII 447 i ESUM V 22 formę ра́мя́ uznają za gwarową. Poza tym znana jest dialektalna forma ра́ма (w ESUM V 22 bez bliższej lokalizacji). Formę раме́но, przytaczaną jeszcze z tekstów z połowy XX wieku, słownik współczesnego języka ukraińskiego uważa za przestarzałą (SUM VIII 446).

Z dialektów białoruskich znana jest forma рамян'о: spod Grodna (SciaszMat 419) oraz z trzech punktów znad granicy litewskiej (SłPogr IV 269). Stanowi ona najpewniej przekształcenie polskiej formy ramiono. Na północy pod Brasławiem zapisano formy ram'e, ramje, ram'ona f., ram'eń $\mathrm{m}$. oraz w liczbie mnogiej ram' jony, ram'ony, ram' jona, ram'ona (Brasławszczyzna II: 10). Formę paMe, którą ze względu na $e$ na miejscu samogłoski nosowej należy przypisać wpływowi języka polskiego (por. ESBM XI 88), notuje słownik Nosowicza 554 oraz historyczny słownik białoruski z XVI-XVII wieku. Pod jednym hasłem podano tam łącznie dosyć trudne do rozdzielenia formy рамя, раме < ${ }^{\star}$ ormę 'ramię', przen. 'władza', moc', a ponadto kilkakrotnie paмo < *ormo 'ramię' i dwukrotnie paмa *ormo (?) 'ramię' z 1489 i 1697 roku (HSBM XXX 3-4).

Gwarowy słownik rosyjski podaje jedynie pamo w znaczeniu 'ręka' z r. 1856 znad Wołgi oraz paмo 'część ręki [od barku] do łokcia' z Dala (SRNG XXIV 98), natomiast w źródłach pisanych formy od rdzenia ${ }^{*}$ orm- poświadczone są w języku rosyjskim dosyć bogato. Srezniewski przytacza kilkanaście przykładów formy рамо w znaczeniu 'ramię', poczynając od Zbornika Swiatosława z 1076 roku, zarówno z przekładów biblijnych, jak i z innych zabytków staroruskich, ma też dwa przykłady formy paм^ m.in. w znaczeniu 'ramię' (SrezMat III 65-66, 67). SRJ XI-XVII, t. XXI 268-269 podaje рамо na oznaczenie następujących części ciała, głównie 'ramię od 1076 r., ale też 'górna część ręki' z XVI wieku oraz 'górna część pleców', 'plecy' z XII i XVII wieku, a poza tym też рамя 'ramię' z XIV-XVIII wieku oraz рамено 'ramię z 1691 roku. Później, jeszcze w XIX wieku, jako przestarzała i poetycka lub żartobliwa używana była forma liczby mnogiej раменá 'ramiona' (SSRLJ XII 575). 
A zatem wschodniej Słowiańszczyźnie nazwy związane z rdzeniem *ormpierwotnie nie były znane: okresowo wystąpił tu cerkiewizm paмo (por. bogato poświadczone pamo w języku starosłowiańskim - SJS III 602) i jego przekształcenie рамено, natomiast na pograniczu zachodnim peryferyjnie pojawiły się przejęte z polskiego formy раме, рамя, рамено, рамень.

Jak już wspomniałem, za formy podstawowe, od których powstały inne, należy uznać ${ }^{\star}$ ormę i ${ }^{\star}$ ormo.

Forma ${ }^{\star}$ ormę tworzy w OLA dwa obszerne areały: na terenie serbsko-chorwackim i polskim. Poza tym sporadycznie pojawia się w wielu innych miejscach.

Do zwartego obszaru serbsko-chorwackiego ('rame, ràme, rã:me itp.) nawiązują punkty wyspowe na Węgrzech (ràme - 150, 152, rà.me - 151) i w Rumunii ('rame-168, 'rame - 169).

Na szerszą znajomość tej formy w południowej Słowiańszczyźnie wskazują materiały spoza OLA. Odosobniony w OLA zapis formy 'ra:me (6) w zachodniej Słowenii i zapewne formy liczby podwójnej *ormi - 'rami (13) w pobliżu Cerknicy, ma szerokie nawiązanie w atlasie słoweńskim: postać rame zanotowano w ok. 50 punktach głównie na pograniczu włoskim na północ od Goricy, ale w rozproszeniu też niemal na całym terytorium słoweńskim (licznie poświadczona jest też ona u Plet II 373, ale w SSKJ IV 315 uważana jest już za przestarzałą), por. SLA 1/29, kom. s. 100. Poza tym Drvošanov 2005: 114 podaje ${ }^{*}$ orme - paмe - z Macedonii w dwóch punktach na północy koło m. Koczani i w dwóch punktach na południu koło $\mathrm{m}$. Gewgelija.

W piśmie na gruncie serbsko-chorwackim formy od rdzenia *orm- są bogato reprezentowane. Räme n., pl. ramèna jest poświadczone od XIV wieku i ma bardzo bogatą dokumentację w słownikach i w różnego typu zabytkach (RSHJ XIII 32-35, RSHKJ V 400).

Drugi obszerny areał z formą ${ }^{*}$ ormę tworzą dialekty polskie. Łączy się z nim punkt na Łużycach (ram'e - 234). Obok niemal ogólnopolskiego ramię (najczęściej ram'e, poza tym też ramje, ramńe, rem'e, remńe itp., w p. 242 na Kaszubach r'emja) występują też liczne formy współrdzenne. Ich zasięgi pozwalają bliżej określić polskie opracowania gwarowe, przede wszystkim dający obraz ogólnopolski MAGP VII 309, s. 33-35. Opracowania te przynoszą też wiele nienotowanych w OLA nazw sporadycznych. Według MAGP l.c. brak formy ramię lokalnie na zachodnim Śląsku i w pasie na prawym brzegu Wisły od Tarnobrzegu po Puławy. W naszych materiałach brak jej natomiast w kilku punktach na peryferii wschodniej $(266,322,325)$, materiały z przesiedleńczych punktów na Dolnym Śląsku nie są dla jej zasięgu reprezentatywne. Na Białostocczyźnie ramię występuje w jej części zachodniej od północy aż po Narew (AGWB V 27, s. 72). 
W polszczý́nie ogólnej od XIV wieku panuje jedna forma ramię (SStp VII 432, Linde V 25, SJPD VII 813-815), zaś zupełnie sporadycznie pojawiło się w słowniku Mymera z 1541 roku ramiono (SP XVI, t. XXXV 103-108). SW V 472-473 uważa ramiono za formę gwarową.

Na terenie Łużyc zanotowano wiele form, m.in. raz ${ }^{\star}$ orme - ram' $\varepsilon$ (234), a raz formę liczby mnogiej ram'zna (236). Forma dłuż. ramje, gen. sg. ramjenja jest poświadczona od XVI wieku (Moller, Megiser, Hauptmann, Muka, Starosta).

Dawniej również w języku czeskim występowało pierwotne *ormę - rámě (Jg III 789-790, Kott III 21-22, PS IV/2, 614-615, SSJČ III 16), ale dziś uważane jest za książkowe i przestarzałe. W OLA nie zanotowano go ani razu. Już dawno zostało zastąpione przez w tórne rameno.

$\mathrm{W}$ północnych dialektach polskich w wyniku zatraty rezonansu nosowego w końcówce doszło do wytworzenia innowacji morfologicznej nie odnotowanej w materiałach OLA. Na znacznym obszarze Polski północnej od Kociewia, Malborsko-Lubawskiego przez Kujawy, ziemię chełmińską, część Mazowsza oraz Warmię i Mazury aż po wschodnią granicę państwową doprowadziło to do powstania odrębnego typu morfologicznego: nom sg. ${ }^{\star}$ ormje - ramie : gen. sg. ramia i nom. pl. ramia jak pole : pola : pola (MAGP VII 316, s. 59). Pewne uściślenia dotyczące zasięgu tego typu morfologicznego w Malborskiem, na Kociewiu, w Borach Tucholskich i nad Notecią przynosi AJK XI 532, s. 152 i XII 567, s. 103-104. Natomiast, koncentrujący się na przejściu $r a>r e$ w tym wyrazie, późniejszy o niemal 30 lat AGM X 50-51 o występowaniu tej innowacji morfologicznej na Mazowszu w ogóle nie wspomina. Tymczasem ten typ morfologiczny ma jeszcze znacznie szerszy zasięg, co pokazuje Dejna w AGP na m. 119 na przykładzie wyrazu siemie 'siemię. Poza wyznaczonym tu terenem występuje on też pod Kaliszem, Sieradzem, Częstochową i Piotrkowem, na południe od Kielc oraz w płd.-wsch. Polsce od Nowego Sącza i Tarnowa aż po Ustrzyki Dolne, por. Siatkowski - Rembiszewska (w druku, z dalszą literaturą).

Forma *ormo - ramo tworzy duży zwarty kompleks w dialektach bułgarskich i macedońskich oraz na terenie Czarnogóry $(73,74,76,77)$ i południowej oraz wschodniej Serbii $(84,85,87)$. Do kompleksu tego nawiązuje też odosobniony punkt bułgarski (ro'mo 167) w rumuńskim Banacie. W dialektach bułgarskich oraz w sąsiadujących punktach na terenie północnej Grecji i w p. 853 na terenie Turcji jest ona w OLA wyłączna, natomiast $w$ dialektach macedońskich (też w zachodniej części północnej Grecji) oprócz ramo notowano też kilka form innych. Tę wielką różnorodność form nazw 'ramienia' w dialektach macedońskich potwierdza Drvošanov (2005, 114-115; niestety nie podając mapy). Według niego forma paмo występuje właściwie na całym terytorium gwar macedońskich. 
Jako formy literackie ustaliły się: mac. рамо, pl. рамена, рамењь (RMJ III 53) i bułg. ра́мо, pl. рамена́ і рамене́ (RSBKE III 87).

W materiałach spoza OLA formę * ormo - ramo zanotowano aż w 19 punktach koło Goricy (z tych stron podawał ją także Plet II 373).

Szczególną dokumentację ma natomiast forma rämo na gruncie serbsko-chorwackim (RSHJ XIII 32-35, RSHKJ V 400), która pojawia się już pod koniec XIV wieku i utrzymuje się w starych zabytkach aż do XVI wieku (u czakawskiego autora Marko Marulicia i u pochodzących z Dubrownika M. Vetranovicia i N. Nalješkovicia), potem zanika i pojawia się ponownie dopiero w XIX wieku w pieśniach. Najpewniej mamy tu do czynienia z cerkiewizmem.

Przedstawione gwarowe układy geograficzne form *ormę i *ormo przemawiają według mnie raczej za pierwotnością na gruncie słowiańskim formy *ormę, występującej w rozproszeniu po całej Słowiańszczyźnie. Tak też ich wzajemny stosunek określany jest w SLA 1/29, kom. s. 100 (z powołaniem się na Logara i Šekliego).

Forma ${ }^{\star}$ ormeno, utworzona od rozszerzonego tematu ${ }^{*}$ ormen- w przypadkach zależnych wyrazu ${ }^{\star}$ ormę, tworzy w OLA kilka zwartych areałów, a ponadto występuje $\mathrm{w}$ wielu rozproszonych punktach.

Największy kompleks obejmuje dialekty czeskie, z którym ściśle łączy się ramyno w punkcie 299 na polskim Śląsku pod Raciborzem. Występowanie tej formy na pograniczu polsko-czeskim po stronie polskiej potwierdza AJŚ VII/2, s. 42, a jeszcze bardziej Dejna PLPJ I m. 111, podający ramiuno - po stronie laskiej zaś rameno pod Głubczycami i ramyno pod Raciborzem. Natomiast ramńono $(257,268)$ i ram'onu $(276)$ w polskich punktach przesiedleńczych na Dolnym Śląsku, jako przeniesione po II wojnie światowej, do ustalania geografii tej formy nie mogą być wykorzystane. Również w języku słowackim pojawiają się, zupełnie niepoświadczone w OLA, formy od rdzenia ${ }^{\star}$ orm- . W słowackim słowniku historycznym wielokrotnie z XVII-XVIII wieku jest poświadczone rameno (HSSJ V 20), a jak informuje mnie Adriana Ferenč́ková, rameno występuje też w słowniku Bernoláka, a po 1918 roku szerzyło się w literackim i potocznym języku słowackim (por. Palkovič 1967, 258) pod wpływem czeskim przez szkołę i wojsko (np. dzięki rozkazowi na rameno zbraň). SSJ III 692, 693 podaje jeszcze rameno oraz jako poetyckie i przestarzałe ramä.

Kolejny areał $\mathrm{z}$ formą *ormeno - rameno występuje w dialektach macedońskich. W OLA zanotowano 'ra'meno tylko w pięciu punktach $(97,102,107$, 108 i w p. 92 pl. ramena), natomiast Drvošanov (2005, 114-115), uważane za dialektalne рамено (RMJ III 52), notował też niemal na całym terytorium macedońskim (jedynie poza płn.-wsch. Macedonią). 
Dla zanotowanej na Łużycach liczby mnogiej 'ram’ena (236) trzeba przyjąć w nom. sg. *ormeno, która ma potwierdzenie w głuż. ramjeno u Hančki z 1782 r. oraz w przestarzałym dłuż. rameno u Muki II 293. Może dotyczy to też formy liczby mnogiej rámena w punkcie słoweńskim (2) na terenie Włoch.

Formę * ormeno n. w dialektach polskich, pomijając niereprezentatywne zapisy z punktów 257, 268 i 276 na Dolnym Śląsku, zapisano w OLA w rozproszeniu pod Oleckiem (remńono - 265), pod Sierpcem (ramjuno - 271), pod Łowiczem (rym'uno - 282) i w Krzanowicach pod Raciborzem (ramyno - 299), w MAGP l.c. zaś, oznaczona izoglosą, występuje zwarcie na zachodnim Śląsku (u nas blisko p. 299; zaś SGPK V 8-9 ramiono podaje z Górnego Śląska), dwukrotnie na zachodzie Mazowsza (u nas blisko p. 271), prócz tego na pograniczu wschodnim pod Radzyniem Podlaskim i pod Lubaczowem. AGM X 50-51 ramiono (reńono) przynosi dodatkowo z dwóch dalszych punktów na Mazowszu wschodnim spod Kolna i Ostrołęki. Według AGWB V 27, s. 72 na Białostocczyźnie ramiono tworzy niewielką wyspę wokół Bielska Podlaskiego (remíno, ramíno, ryḿono / rumíono), poza tym występuje sporadycznie koło Sokółki (ramian'o). Ramiono częste jest również na pograniczu polsko-czeskim na Śląsku (por. wyżej). Podobnie rozproszone zasięgi, ze szczególną koncentracją na pograniczu wschodnim, ma wtórny typ siemiono 'siemię' w AGP Dejny (m. 119). Dla zapisanych w OLA pod Hrubieszowem (324) form liczby mnogiej ram'eńa, ram'ona trudno jednoznacznie ustalić postać liczby pojedynczej, choć dane z MAGP przemawiają w wypadku drugiej formy raczej za formą ramiono.

$\mathrm{Z}$ polskiego ${ }^{\star}$ ormeno - rameno, ramiono przeszło też do sąsiednich gwar ukraińskich (notowane w OLA) i białoruskich (por. wyżej).

Forma ${ }^{\star}$ orma f. - rama tworzy zwarty kompleks na południowym zachodzie, obejmujący dialekty słoweńskie oraz kilka punktów $(26,29,32,35)$ na terenie zachodniej Chorwacji. W punktach słoweńskich 18 i 19 zapisano też formy liczby mnogiej ra:me - ${ }^{\star}$ ormę. W atlasie słoweńskim (SLA 1/29, kom. s. 100) forma rama, właściwa też słoweńskiemu językowi literackiemu (rama f., pl. rame notowana przez Plet II 373 oraz SSKJ IV 315), występuje na całym niemal terytorium słoweńskim. Bliższych informacji o zasięgu formy rama f. na gruncie serbsko-chorwackim nie potrafię podać. Skok III 105-106 podawał ją ze słownika Vuka (pisze o niej też RHSJ XIII 39 s. v. ramo). Ponadto Drvošanov $(2005,114-115)$ podaje ${ }^{\star}$ orma - paмa z 5 punktów w pobliżu Kumanowa. Może więc też zapis 'ramə w p. 105 należy traktować jako *orma.

Formę męską *ormens, utworzoną od rozszerzonego tematu *ormen-, zanotowano w OLA w rozproszeniu: w zachodniej Chorwacji: 'ramen - (22), w punktach chorwackich na terenie wschodniej Austrii: rã:mę (146a), 'ra:men (147a), 'ramen (148a) i w zachodnich Węgrzech 'roumen (153), w kilku punktach 
polskich: na Kaszubach 'rẹmjẹn (241) i na południowym wschodzie rẹm’ẹi (313), ram'iń $(322,324)$, ram'ẹn $(325)$ oraz w sąsiednich punktach na zachodniej Ukrainie: 'ramyn (412, 'ram'in' (420).

Źródła porównawcze przynoszą dalsze potwierdzenia tej innowacji: SLA 1/29, kom. s. 100 ma z dwóch punktów słoweńskich râmen (po stronie włoskiej na południe od Goricy) i 'råmän (na północnym wschodzie na północ od Murskiej Soboty), Drvošanov $(2005,115)$ paмuн' z punktu Wysoka pod Sołuniem, forma ramen m. ma dwa poświadczenia u czakawskiego pisarza XVI wieku Marko Marulicia, a potem dopiero z XIX wieku z pieśni ludowych Chorwatów węgierskich (Jačke), por. RHSJ XIII 35, z Łużyc znany jest ramjeń, gen. sg. ramjenja u Megisera (1603), Frentzla (pocz. XVIII w.), Pfula i Rězaka (por. Schuster-Šewc III 1205). Szeroką znajomość tej formy w południowo-wschodniej Polsce, zwłaszcza zaś w zachodniej Lubelszczyźnie i Tarnobrzeskiem, potwierdza MAGP VII 309, s. 34-35. Poza tym MAGP 1.c. ma też przykłady na formę ramień m. ze Śląska (por. też AJŚ VII/2, s. 42) i ze wschodniego Mazowsza. Sychta zaś podaje ramńan / ramńin m. z Kociewia (SychKoc III 54), a AGWB V 27, s. 72 remíon spod Hajnówki. Podobnie szeroki zasięg tego typu morfologicznego pokazuje Dejna w AGP na m. 119 na przykładzie wyrazu siemień 'siemię'.

Formę ${ }^{\star}$ orm $b=o$ n. zapisano w OLA w dwóch punktach $(235,237)$ łużyckich ram'îj oraz w dwóch punktach polskich: na Kaszubach $\left(r y^{j} m^{\prime j} o\right.$ 243) i w zachodniej Wielkopolsce koło Babimostu (rọm' jo 258). Ma ona bogate potwierdzenie w materiałach spoza OLA.

Górnołużyckie ramjo, gen. sg. ramjenja występuje od XVII wieku (Frentzel, Swótlik, Pful, Kral, Jakubaš), por. Schuster-Šewc III 1205.

Polskie ramio (też z o ścieśnionym na końcu) notowano w rozproszeniu na północy na Kaszubach i koło Świecia oraz na południu koło Bochni, Myślenic i Limanowej (MAGP VII 309, s. 35). AJŚ VII/2, s. 42 ma raḿo spod Częstochowy. Najwięcej przykładów formy ramio odnotowano w AJK. Wprawdzie nie ma tu mapy przedstawiającej realizację zakończenia -e w tym typie, bo mapa XIV 656, s. 63 ramię została sporządzona ze względu na przejście ra- > re- w tym wyrazie, a zakończenie - o jest zasygnalizowane tylko przykładowo $\mathrm{z}$ dwóch punktów, a w serii map VIII 377-380, poświęconych pokazaniu sufiksów -ę i -ak w nazwach istot młodych, w przykładach typu ciele, jagnię, źrebię, szczenię itp. zakończenie -o też podawane jest tylko wybiórczo. Najwięcej informacji o formie ramio na terenach objętych przez AJK znajdujemy natomiast w komentarzu do map form gen. sg. i nom. pl. od ramię (XI 532, s. 152 i XII 567, s. 103-104). Formie gen. sg. remia, ramia w kaszubskich gwarach południowo-zachodnich oraz w Skrzeszewie na południowy wschód od Kartuz i w jednym punkcie na 
Kociewiu odpowiada nom. sg. zakończony na -o. Formę tę z Kaszub przytacza też SGPK V 8, powołując się na rêmio u Hilferdinga oraz Lorentz GPom III 911 i PW II 110, podając rämo spod Kartuz i Kościerzyny. Materiały kaszubskie pokazują, że mamy tu do czynienia z przejściem do innego typu deklinacyjnego od ramię : ramienia do ramio : ramia. Przytoczony materiał pozwala tłumaczyć formy typu ramio, remio morfologicznym wpływem odmiany twardotematowej na miękkotematową, jak w wypadku polskich form gwarowych typu polo z pierwotnego pole. Warto dodać, że w MAGP VI 274, s. 88-90 w wielu punktach, gdzie zapisano ramio występują też formy cielo, kurczo. Na Kaszubach typ remio mógł się jednak pojawić też w wyniku przekształceń fonetycznych, zachodniej części środkowych Kaszub właściwy jest bowiem rozwój nosówki przedniej $e>q>a ̊ a$, por. AJK XIII 633, s. 188-189.

Formę *ormenbje, utworzoną od rozszerzonego tematu *ormen-, przeniesionego do mianownika zapisano w OLA sporadycznie w Domaniewku pod Łęczycą (281) - ram’iné (z tej miejscowości potwierdza ją też SGD Szymczaka). W źródłach porównawczych ma ona znacznie szerszy zasięg. MAGP VII 309, s. 35 notuje ramienie (ramienie, raminie itp.) z ośmiu rozproszonych punktów północnej połowy Polski, SGPK V 8 raz z Górnego Śląska, ale poza tym spory zwarty kompleks złożony z kilkunastu punktów tworzy ona (ramíeń'e, ramyń'e, r'ermeńé itp.) na Białostocczyźnie w części zachodniej na południe od Białegostoku (AGWB V 27, s. 72; na mapie przedstawiono ją tu błędnie pod reḿ́ono). U Dejny w AGP na m. 119 ten wtórny typ morfologiczny reprezentuje wyraz siemienie 'siemię', notowany w rozproszeniu, głównie zaś na wschodzie Polski koło Suwałk, Białej Podlaskiej i Zamościa. Inaczej należy traktować sporadyczną sch. formę coll. rameńe 'ramiona' u jednego pisarza z XVI wieku, z pieśni ludowej w zbiorze Vuka i jako dialektalne z Kosowa (RHSJ XIII 36).

Lorentz GPom III 911 i PW II 110 podaje sporadyczne zastąpienie zakończenia -e przez -o w formie rämeńo występującej w kilku punktach pod Kartuzami, a Dejna PLPJ I m. 111 ramińo z dwóch punktów pod Raciborzem, Sobierajski III m. 288 zaś z dwóch punktów ze słowackiego Spisza (raḿeńo, raminó). Należy tu widzieć przekształcenie wyrównanie pod wpływem tematów twardych typu lato.

W Radziuszkach pod Sejnami (266) zanotowano sporadyczne formy żeńskie ram’a ( ${ }^{*}$ orm-b=-a) i rameńa ( ${ }^{*}$ ormenoja). MAGP VII 309, s. 34 podaje ramia jako formę żeńską właśnie z Radziuszek i z punktu przesiedleńczego z informatorami spod Nowych Trok na Wileńszczyźnie. Formy żeńskie ramia i ramienia notuje też Zdancewicz (1958, 214; 1966, 97) spod Sejn, a ramia też Szymczak SGD 904 z Domaniewka pod Łęczycą i Dejna PLPJ I m. 111 w kilku punktach na pograniczu polsko-laskim na południe od Bukowa i Krzyżanowic. Poza tym na mapie 
MAGP l.c. znajdujemy tu jeszcze kilka punktów z formą ramia, ale bez wyraźnego stwierdzenia, że jest to forma żeńska: na północy z Luzina pod Wejherowem, z Zawor pod Kartuzami, ze Studzienic pod Bytowem i z Łęgu pod Chojnicami, z Woryt pod Olsztynem oraz na południu z Jędryska pod Lublińcem, z Bełku i Olzy pod Rybnikiem i z Tylmanowej spod Nowego Targu.

Natomiast zanotowana w Macedonii forma rameńa (100) stanowi formę liczby mnogiej od ramo, a w polskim punkcie 324 ram'eńa chyba formę pl. od ramień.

W punkcie przesiedleńczym pod Pasłękiem (252) zanotowano formę żeńską (ta) ram’ona, która też ma potwierdzenie w MAGP VII 309, s. 34 z Sumowa pod Sejnami oraz ze wspominanego punktu przesiedleńczego $\mathrm{z}$ informatorami spod Nowych Trok (ta ostatnia lokalizacja znajduje potwierdzenie u Zdaniukiewicza 1958, 195).

Zanotowaną w OLA w Macedonii sporadycznie pod Skopjem formę *ormenica - ramenica (95) potwierdza z dwóch dalszych punktów koło Skopja Drvošanov $(2005,114-115)$ (раменица). Poza tym Gerov V 72 notuje bułg. рамени́иа, а RSHKJ V 400 sch. рамѐница chyba z Wojwodiny.

W Macedonii zapisano sporadycznie formę ra'mijka (105), którą chyba należy uogólnić jako *ormenıka.

Z materiałów spoza OLA można podać jeszcze sporadyczne raménak, раме́нак u czakawskiego pisarza z XVI wieku Hektorovicia (RHSJ XII 36, RSHKJ V 400) oraz deminutiva raménce, раме́нu,e z pieśni w okolicy Dubrownika m.in. na wyspach Korčula i Lastovo (RHSJ XII 36, RSHKJ V 400).

W znaczeniu 'ramię' zanotowano w OLA jeszcze kilka nazw zupełnie sporadycznych. Dla brus. burka (362) i ukr. obol'čyk (449) nie znalazłem żadnych nawiązań. Ros. kłubok (578 - $\left.{ }^{\star} k l q b ъ k z\right)$ można łączyć z ros. dial. клубкú

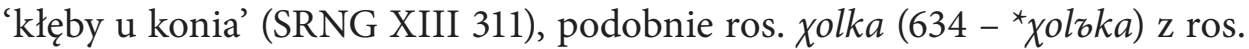
i ukr. холка 'kłąb zwierzęcia' (Vasmer ESRJ IV 255). Ten ostatni wyraz tworzy znaczny areał na północy Rosji w znaczeniu 'udo' (Siatkowski 2012a, 180-181).

Przedstawione nazwy 'pleców' i 'ramienia' wykazują dużą wieloznaczność, stwierdzaną też przy innych nazwach części ciała (por. Siatkowski 2012b, 151-157). Niektóre nazwy 'pleców' odnoszą się często też tylko do ich części górnej lub dolnej, a także do 'kręgosłupa', a pewne nazwy 'ramienia' oznaczają też 'bark', 'górną część ręki do łokcia” lub 'całą rękę aż do dłoni'. Prowadzi to nawet do mieszania nazw 'pleców' i 'ramienia'. 
Nazwy 'ramienia' od rdzenia ${ }^{\star}$ orm- wykazują wielkie zróżnicowanie morfologiczne. Brak w zapisach OLA informacji o formach gramatycznych utrudnia ich interpretację. Wyjaśnienie skomplikowanych przekształceń morfologicznych tych form ułatwiają dopiero materiały porównawcze spoza OLA. Materiały te poza tym odnotowaną w OLA różnorodność morfologiczną tych nazw znacznie powiększają. Materiały historyczne pokazują, że leksem ten pierwotnie we wschodniej Słowiańszczyźnie nie był znany.

\section{Literatura}

AGM - Atlas gwar mazowieckich, 1971-1992, t. I opr. H. Horodyska-Gadkowska, A. Strzyżewska-Zaremba, t.II-Xopr. A. Kowalska, A. Strzyżewska-Zaremba, Wrocław. AGP - Atlas gwar polskich, 1998-2002, 1. Małopolska, 1998, K. Dejna, 2. Mazowsze, 2000, K. Dejna, S. Gala, A. Zdaniukiewicz, F. Czyżewski, 3. Ślask, 2001, K. Dejna, S. Gala, 4. Wielkopolska, Kaszuby, 2002, K. Dejna, Warszawa.

AGWB - Atlas gwar wschodniosłowiańskich Białostocczyzny, 1980-2012, t. I, red. S. Glin ka, A. Obrębska-Jabłońska, J. Siatkowski, Wrocław 1980, t.II-III, red. S. Glinka, Wrocław 1989-1993, t. IV-X red. I. Mar yniakowa, Warszawa 1995-2012.

AJK - Atlas językowy kaszubszczyzny i dialektów sasiednich, 1964-1978, opr. przez Zespół Zakładu Słowianoznawstwa PAN pod kier. Z. Stiebera, od z. VII pod kier. H. Popowskiej-Taborskiej, I-XV, Wrocław.

AJŚ - A. Zaręba, 1969-1996, Atlas językowy Śląska, Kraków, I-VIII, Warszawa - Kraków, Warszawa.

BASRJ - Большой академический словарь русского языка, 2004 и сл., ред. Г. Н. Скля ревская, Москва.

BER - Български етимологичен речник, 1971 і п., ред. Вл. Георг иев (И. Дуриданов, М. Рачева, Т.А. Тодоров), София.

Bezlaj F., 1977-2005, Etimološki slovar slovenskega jezika, I-IV, Ljubljana.

Boryś SE - Boryś W., 2005, Stownik etymologiczny języka polskiego, Kraków.

Brasławszczyzna. Pamięć i wspótczesność. Tom II. Słownictwo dwujęzycznych mieszkańców rejonu (Słownik brasławski), red. naukowy E. Smułkowa, Warszawa 2009.

Br ückner A., 1914, Die litauische Spracheinheit, „Zeitschrift für vergleichende Sprachforschung auf dem Gebiete der indogermanischen Sprachen" 46, s. 217-239.

Brückner SE - A. Brückner, 1957, Stownik etymologiczny języka polskiego, Warszawa.

$\mathrm{BTR}^{4}$ - Български тълковен речник, 1996, ред. Л. Андрейчи и и др. Четвърто издание допълнено и преработено от Д. Попов, София.

Čekman - В. Н. Чэкман, 1972, К проблеме литовско-белорусских лексических саязей, „Baltistica” VIII, s. 147-156.

ČJA - Českýjazykovýatlas, 1992-2005, red. J. Balhar, P. Ja nčák, I-V, Praha. 
Dal - Вл. Даль, 1955-1956, Толковый словарь живого великорусского языка, I-IV, Москва. Dejna PLPJ - K. Dejna, 1951-1953, Polsko-laskie pogranicze językowe na terenie Polski, I-II, Łódź.

Drvošanov - В. Дрвошанов, 2005, Анатомската лексика за човекот во македонските говори, Скопје.

ESBM - Этымалагічны слоўнік беларускай мовы, 1978-, рэд. В. У. Мартынаў, Мінск.

ESJS - Etymologický slovnik jazyka staroslověnského, 1989-, red. E. Havlová, A. Erhart, Praha.

ESSJ - Этимологический словарь славянских языков. Праславянский лексический фонд, 1974-, ред. О. Н. Трубачев, Москва.

ESUM - Етимологічний словник української мови, 1982-2012, ред. О. С. Мельн ичук, I-VI, Київ.

Gerov - Н. Геров, 1975-1978, Речник на българския език с тълкувание речите на български и на руски, I-V, София.

Horbač - О. Горбач, 1969, Говірки Теребовельщини, Мюнхен.

Hrinč - Б. Грінченко, 1907-1909, Словарь української мови, I-IV, Київ.

HSBM - Гістарычны слоўнік беларускай мовы, 1982-, рэд. А. Жураўскі, Мінск.

HSSI - Historický slovník slovenského jazyka, 1991-2008, red. M. Majtá n, I-VII, Bratislava. Jg - J. Ju ng ma n n, 1835-1839, Slovník česko-německý, I-V, Praha.

Korolko - A. F. Modrzejewski, 2003, O poprawie Rzeczypospolitej. Księgi czwore, opr. M. Korolko, Piotrków Trybunalski.

Kott - F. Š. Kot t, 1878-1893, Česko-německý slovník, zvláště gramaticko-frazeologický, I-VII, Praha.

Linde - Linde M.S. B., 1854-1860, Słownik języka polskiego, I-VI, Lwów, wyd. 3. fotoofsetowe, Warszawa 1951.

Lorentz GPom - F. Lorentz, 1958-1962, Gramatyka pomorska, I-III, Wrocław.

Lorentz PW - F. Lorentz, 1958-1983, Pomoranisches Wörterbuch, fortgeführt von F. Hinze, $\mathrm{I}-\mathrm{V}$, Berlin.

MachES-2 - V. Machek, 1968, Etymologický slovník jazyka českého, Praha.

MAGP - Mały atlas gwar polskich, 1957-1970, opr. przez Pracownię Atlasu i Słownika Gwar Polskich Zakładu Językoznawstwa PAN w Krakowie pod kier. K. Nitscha, od t. III pod kier. M. Karasia i Z. Sta mirowskiej, od t. IX pod kier. M. Karasia, I-XIII, Wrocław. Miklosich - F. Miklosich, 1886, Etymologisches Wörterbuch der slavischen Sprachen, Wien. MSČS - J. Bělič, A. Ka miš, K. Kučera, 1978, Malýstaročeský slovník, Praha.

Muka A., 1911-1928, Słownik dolnoserbskeje rěcy a jeje narěcow. Wörterbuch der niedersorbischen Sprache und ihren Dialekte, I-III, Petrograd - Praha.

Nosowicz - I. I. Носовіч, 1870, Слоўнік беларуского нарпчія, Спб.

OLA 9 - Общеславянский лингвистический атлас. Серия лексико-словообразовательная, вып. 9. Человек. Ogólnosłowiański atlas językowy, Seria leksykalno-słowotwórcza, t. 9. Człowiek, 2009, red. J. Siatkowski, J. Waniakowa, Kraków.

Palkovič K., 1967, Názvy častí tela v češtine a slovenštine, „Kultúra slova” I, s. 257-261.

Plet - M. Pleteršnik, 1894-1895, Slovensko-nemški slovar, I-II, Ljubljana. 
PS - Příruční slovník jazyka českého, 1933-1957, I-VIII, Praha.

Radziwiłł 1998 - Hieronima Floriana Radziwiłła Diariusze i pisma różne, opracowanie i wstęp M. Brzezina, Warszawa.

RBE - Речник на българския език, 1977-, ред. К. Чолакова, София.

RHSJ - Rječnik hrvatskoga ili srpskoga jezika, 1880-1976, I-XXIII, Zagreb.

RMJ - Речник на македонскиот јазик со српскохрватски толкувана, 1961-1966, ред. Б. Конески, I-III, Скопје.

RSBKE - Речник на съвременния български книжовен език, 1955-1959, ред. Ст. Роман ск и, I-III, София.

RSHJ - Речник српскохрватског книжевног и народног језика, 1959-, Београд.

RSHKJ - Речник српскохрватскога књижевног језика, 1967-1976, Матица спрска - (Матица хрватска), I-VI, Нови Сад - (Загреб).

Schuster-Š ewc H., 1978-1996, Historisch-etymologisches Wörterbuch der ober- und niedersorbischen Sprache, I-V, Bautzen.

SciaszMat - Т. Ф. Сц я ш ковіч, 1972, Матэрыяль да слоўніка Гродзенскай вобласиі, Мінск.

SDUP - Studia nad dialektologia polska i ukraińska (Z materiałów b. Katedry Języków Ruskich UJ), 1975, opracował do druku M. Karaś, Kraków.

SGD - M. Szy mczak, 1962-1973, Słownik gwary Domaniewka w powiecie łęczyckim, I-VIII, Wrocław.

SGPA - Słownik gwar polskich, 1977-, opr. przez Zakład Dialektologii Polskiej Instytutu Języka Polskiego PAN w Krakowie pod kier. M. Karasia, od t. II pod kier. J. Reichana, od t. VI pod kier. J. Okoniowej, Wrocław

SGPK - J. Karłowicz, 1900-1911, Słownik gwar polskich, I-VI, Kraków.

Siat kowski J., 2012a, Słowiańskie nazwy części ciała w historii i dialektach, Warszawa.

Siat kowski J., 2012b, Wieloznaczność i geografia słowiańskich nazw części ciała, „Z polskich studiów slawistycznych, ser. XII: Językoznawstwo”, Warszawa, s. 151-157.

Siatkowski J., 2013, Wschodniosłowiańska spina 'plecy' pożyczkq z polskiego?, „Poradnik Językowy" 3, s. 36-40.

Siatkowski J., Rembiszewska D. K., Zróżnicowanie morfologiczne wyrazu *ormę 'ramię' w językach i dialektach słowiańskich, Bratysława (w druku).

SJPD - Słownik języka polskiego, 1958-1969, red. W. Doroszewski, I-XI, Warszawa.

SJS - Slovník jazyka staroslověnského, 1966-1997, red. J. Kurz, Z. Hauptová, I-IV, Praha.

Skok P., 1971-1974, Etimologijski rječnik hrvatskoga ili srpskoga jezika, I-IV, Zagreb.

SLA - Slovenski lingvistični atlas 1: Človek (telo, bolezni, družina), 2011, red. J. Škofic, 1. Atlas, 2. Komentarji, Ljubljana.

Sławski SE - F. Sławski, 1952-1982, Słownik etymologiczny języka polskiego, I-V, Kraków.

SłPogr - Слоўнік беларускіх гаворак паўночна-заходняй Беларусі і яе пагранічча у пяиі maмах, 1979-1986, рэд. Ю. Ф. Мацкевіч, I-V, Мінск.

Snoj M., 1997, Slovenski etimološki slovar, Ljubljana.

Sobierajski Z., 1966-1977, Atlas polskich gwar spiskich na terenie Polski i Czechosłowacji, I-IV, Poznań. 
SP - Słownik prasłowiański, 1974-, opr. Zespół Zakładu Słowianoznawstwa PAN, red. F. Sławski, Wrocław.

SP XVI - Słownik polszczyzny XVI wieku, 1966-, red. M. R. Mayenowa, (F. Pepłowski, K. Mrowcewicz), Wrocław.

SrezMat - И. И. Срезневский, 1893-1912, Материаль для Словаря древнерусского языка, I-III, Санкт-Петербург.

SRJ XI-XVII - Словарь русского языка XI-XVII вв., 1975-, ред. С. Г. Бархударов (Ф. П. Филин, Д. Н. Шмелев, Г. А. Богатова, В.Б. Крысько), Москва.

SRJ XVIII - Словарь русского языка XVIII века, 1984-, ред. Ю. С. Сорокин (З. М. Петрова), Ленинград (Санкт-Петербург).

SRNG - Словарь русских народных говоров, 1965-, составил (с II т. гл. ред.) Ф. П. Ф ил ин, Москва - Ленинград.

SSA - Sorbischer Sprachatlas, 1965-1996, I-X, bearb. von H. Faßke, H. Jentsch und S. Michalk, XI-XV von H. Faßke, Bautzen.

SSJ - Slovník slovenského jazyka, 1959-1968, red. Š. Pecia r, I-VI, Bratislava.

SSJČ - Slovník spisovného jazyka českého, 1960-1971, red. B. Hav rá nek, I-IV, Praha.

SSKJ - Slovar slovenskega knjižnega jezika, 1970-1991, I-V, Ljubljana.

SSN - Slovník slovenských nárečí, 1994-, red. I. Ripka, Bratislava.

SSRLJ - Словарь современного русского литературного языка, 1950-1965, ред. Ф. П. Фи лин, I-XVII, Москва - Ленинград.

SStp - Słownik staropolski, 1953-2004, red. S. Urbańczyk, I-XI, Warszawa - Kraków.

SSUM - Словник староукраӥнської мови XIV-XV cm., 1977-1978, ред. Л. Л. Гумецька, I-II, Київ.

Stčsl - Staročeský slovník, 1977-, red. B. Havránek, F. Ryšánek, I. Němec, Praha.

SUM - Словник української мови, 1970-1980, ред. І. К. Бі лодід, I-XI, Київ.

SUM XVI-XVII - Словник української мови XVI - першої половини XVII cm., 1994-, ред. Д. Гринчишин, Львів.

SW - Słownik języka polskiego, 1908-1927, red. J. Karłowicz, A. Kryński, W. Niedźwiedzki, I-VIII, Warszawa (tzw. Słownik warszawski).

SWil - Słownik języka polskiego, 1861, opr. A. Zd a nowicz, M. Bohusza Szyszkę i in., I-II, Wilno (tzw. Słownik wileński).

SychKoc - B. Sychta, 1980-1985, Słownictwo kociewskie na tle kultury ludowej, I-III, Wrocław.

Škaljić A., Turcizmi u srpskohrvatskom jeziku, Šesto izdanje, Sarajevo 1989.

TRMJ - Толковен речник на македонскиот јазик, 2003-, гл. ред. К. Конески, Скопје.

Trubačev ESSJP - О.Н. Трубачев, 1963, Этимологический словарь словянских языков. Проспект. Пробные статьи, Москва.

TSBM - Тлумачальны слоўнік беларускай мовы, 1977-1984, рэд. К. К. Ат раховіч (К. Крапіва), I-V, Мінск.

Tymс̌enko - Є. Тимченко, 2002-2003, Матеріали до словника писемної та книжної української мови XV-XVIII cm., I-II, Підготували до видання В. В. Ні мч ук та Г. І. Л иса.

Vasmer ESRJ - М. Фасмер, 1964-1973, Этимологический словарь русского языка, Перевод с нем. и дополнения О. Н. Трубачев а, I-IV, Москва. 
Vasmer REW - M. Vasmer, 1950-1958, Russisches etymologisches Wörterbuch, I-III, Heidelberg. Werenicz - В. Л. Веренич, 1990, Польско-белорусское взаимодействие (на материале мазурского островного говора в Полесье), [w:] „Studia nad polszczyzną kresową”, t. V, red. J. Rieger, W. Werenicz, Wrocław, s. 7-141.

Zdancewicz 1958 - T. Zdancewicz, Z zagadnień gwar przejściowych pogranicza polsko-białoruskiego, [w:] „Z polskich studiów slawistycznych”, t. I, Warszawa, s. 205-215.

Zdancewicz 1966 - T. Zd ancewicz, Wpływy białoruskie w polskich gwarach pod Sejnami, Poznań.

Zdaniukiewicz 1972 - A. A. Zd aniukiewicz, Gwara Łopatowszczyzny. Fonetyka, fleksja, słownictwo, Wrocław.

\section{Slavic names of 'the back' and 'the shoulders' in the light of dialectal materials and historic sources}

\section{(Summary)}

The meaning of the names of 'the back' and 'the shoulders' are very ambiguous, which is also characteristic of the other names of the parts of the body. Certain names of 'the back' often refer to only their upper or lower part, as well as to 'the spinal column', while certain names of 'the shoulders' also mean 'the shoulder', 'the upper part of the arm, however, below the elbow' or 'the whole arm to the palm'. In the plural form, this causes the confusion between 'the back' and 'the shoulders'.

'The back' and 'the shoulder' have only one group of common indigenous names: ${ }^{*}$ pletji, ${ }^{\star}$ pletj-E and several word-forming derivates. In the both meanings, one form - ${ }^{*}$ pletji - occurred, which was characterized by an obvious territorial difference. In addition, in the names of 'the back', the names: spina

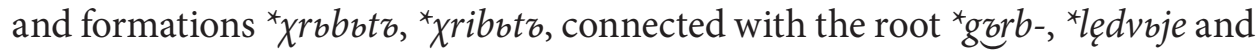
${ }^{*} z a d a$ cover wide territories. The remaining ones are extremely rare.

In the names of 'the shoulders', however, apart from the lexemes connected with the root ${ }^{*}$ pletj-, names derived from the root ${ }^{*}$ orm-, exhibiting a great morphological differentiation, occur. Lack of information in OLA records about grammatical forms somewhat complicates their interpretation. The clarification of complicated morphological transformations of these forms is made easier only by materials derived from beyond OLA. Historical materials prove that in eastern Slavic languages originally the names derived from the root ${ }^{*}$ orm - were unknown. 